\title{
Natural Durability of Timber Exposed Above Ground - a Survey
}

\section{Prirodna trajnost drva izloženoga iznad zemlje - pregled istraživanja}

\author{
Review paper $\bullet$ Pregledni rad \\ Received-prispjelo: 16. 5. 2012. \\ Accepted-prihvaćeno: 15. 2. 2013. \\ UDK: $630 * 841.526$ \\ doi:10.5552/drind.2013.1221
}

\begin{abstract}
Besides its inherent resistance against degrading organisms, the durability of timber is influenced by design details and climatic conditions, making it difficult to treat wood durability as an absolute value. Durability classification is, therefore, based on comparing performance indicators between the timber in question and a reference timber. These relative values are grouped and related to durability classes, which can refer to a high range of service-lives. The insufficient comparability of such durability records has turned out to be a key challenge for service-life prediction.

This paper reviewed literature data, based on service-life measures, not masked by a durability classification. It focused on natural durability of timber tested in the field above-ground. Additionally, results from ongoing aboveground durability studies in Europe and Australia are presented and have been used for further analysis. In total, 163 durability recordings from 31 different test sites worldwide based on ten different test methods have been considered for calculation of resistance factors. The datasets were heterogeneous in quality and quantity; the resulting resistance factors suffered from high variation. In conclusion, an open platform for scientific exchange is needed to increase the amount of available service-life related data.
\end{abstract}

Keywords: durability classes, field tests, resistance factor, service life prediction, test methodology, use class 3

SAŽETAK • Osim otpornosti drva prema štetnim organizmima, na prirodnu trajnost drva utječe i dizajn detalja na proizvodima od drva te klimatski uvjeti, pa je teško razmatrati svojstvo trajnosti drva kao apsolutnu vrijednost. Stoga je klasifikacija trajnosti drva utemeljena na usporedbi pokazatelja izgleda drva, čija se trajnost određuje prema izgledu referentne drvne građe. Te su relativne vrijednosti grupirane i povezane s klasama trajnosti, što se može odnositi na veliki raspon životnog vijeka drvnih proizvoda. Nedovoljna usporedivost takvih zapisa trajnosti pokazala se kao ključni izazov za predviđanje životnog vijeka drvnih proizvoda.

U radu se daje pregled literaturnih podataka utemeljenih na životnom vijeku drvnih proizvoda koji nisu maskirani klasifikacijom trajnosti. Naglasak je na prirodnoj trajnosti drva ispitanoj pri izloženosti drva iznad zemlje. Osim toga, prezentirani su rezultati aktualnih istraživanja prirodne trajnosti drva iznad zemlje u Europi i Australiji te su

\footnotetext{
${ }^{1}$ Author is professor at Leibniz University Hannover, Faculty of Architecture and Landscape Science, Institute of Vocational Sciences in the Building Trade (IBW), Hannover, Germany. ${ }^{2}$ Author is researcher at Norwegian Forest and Landscape Institute, Ås, Norway. ${ }^{3}$ Author is professor at University of Ljubljana, Biotechnical Faculty, Department of Wood Science and Technology, Ljubljana, Slovenia. ${ }^{4}$ Author is professor at Faculty of Horticulture and Forestry Science, Department of Employment Economic Development and Innovation, Ecosciences Precinct, Brisbane, Australia. ${ }^{5}$ Author is researcher at Norwegian Institute of Wood Technology, Oslo, Norway. ${ }^{6}$ Author is researcher at SP Technical Research Institute of Sweden, Department of Wood Technology, Borås, Sweden.

Autor je profesor aSveučilištu Leibniz u Hannoveru, Fakulteta arhitekture i krajobraznih znanosti, Institut za strukovne znanosti u građevinarstvu (IBW), Hannover, Njemačka. ${ }^{2}$ Autor je istraživač u Norveškome šumarskom i krajobraznom institutu, Norveška. ${ }^{3}$ Autor je profesor Sveučilišta u Ljubljani, Biotehnički fakultet, Odjel za znanost i tehnologiju drva, Ljubljana, Slovenija. ${ }^{4}$ Autor je profesor Fakulteta hortikulture i šumarstva, Zavod za zapošljavanje, ekonomski razvoj i inovacije, Brisbane, Australija. ${ }^{5}$ Autor je istraživač na Norveškom institutu drvne tehnologije, Oslo, Norveška. ${ }^{6}$ Autor je istraživač u Tehničkom institutu Švedske, Odjel za drvnu tehnologiju, Borås, Švedska.
} 
iskorišteni za daljnju analizu. U obzir za izračun faktora otpornosti uzeta su ukupno 163 podatka o trajnosti drva dobivena 31 različitoga ispitnog mjesta u svijetu na temelju deset različitih metoda ispitivanja uzeti . Skupovi podataka su heterogeni s obzirom na kvalitetu i količinu, što je rezultiralo velikom varijacijom čimbenika otpornosti. Zaključno, potrebna je otvorena platforma za znanstvene razmjene kako bi se povećala količina dostupnih podataka o životnom vijeku proizvoda.

Ključne riječi: klase trajnosti, terenska ispitivanja, faktor otpornosti, predviđanje životnog vijeka, metodologija ispitivanja, uporabna klasa 3

\section{INTRODUCTION}

\section{UVOD}

The natural durability of timber products is influenced by the interaction of wood properties, environmental conditions and structural design. Wood anatomy and the presence of natural protective chemicals (extractives) provide resistance against biodeterioration by microorganisms and insects. Communities of wood-destroying organisms vary between different locations, and their activity is influenced by climatic factors. Fungal decay and termite attack, for example, are generally more severe in warm and humid environs (Scheffer, 1971; Brischke, 2007; MacKenzie et al., 2007; Thelandersson et al., 2011). The extent to which timber components are affected by biodeterioration and weathering is also mediated by the design and maintenance of timber structures; for instance, the position of different structural elements and use of surface coatings alter their rates of wetting and drying, while untreated joinery and cracks in poorly maintained timber coatings may trap water and thus support decay (Norton and Francis, 2008).

Worldwide building codes and standards have traditionally provided natural durability information in a prescriptive context. Timber species are generally categorized into heartwood durability classes and the allowable uses of timbers belonging to those durability classes are prescribed (Stirling, 2009). Criteria for natural durability classification differ between countries and include combinations of field test data, laboratory test data, history of performance and expert experience (CEN, 1994; CEN, 2006; Standards Australia, 2008).

Many different field and laboratory tests are used to measure natural durability. These include standardized and non-standardized methods, among which test environments, configurations and evaluation methods vary widely (Gobakken and Viitanen, 2004; Råberg et al.; 2005; Stirling, 2009; Fredriksson, 2010). Tests that present a high biodeterioration hazard often involve soil contact or inoculation with microorganisms or insects. Above ground field tests generally pose a lower biodeterioration hazard, but most test configurations are designed to accelerate decay by various moisture trapping elements. Durability evaluation procedures for field tests commonly involve objective or subjective measures of strength loss, while mass loss is commonly measured for laboratory tests. Traditionally, field test results are reported in a variety of ways, including mean or median measures of specimen service life or arbitrary scores that represent levels of biodeterioration. The performance of test species is commonly compared with the ones of non-durable reference species such as the sapwood of Scots pine (Pinus sylvestris L.) or southern yellow pine (Pinus spp.) for softwoods and common beech (Fagus sylvatica L.) wood for hardwoods. Beyond the relative performance of specimens in the circumstances of each test, however, the practical implications of durability test data are only beginning to be explored. Willeitner and Peek (1997) highlighted that comparing different durability tests is difficult, as in addition to the heterogeneity of test methodology, one may face results that are mostly codified - sometimes in a cryptic way - or even incompletely published.

A major challenge remains to extract information from durability tests to help quantify the key factors that affect natural durability and integrate this information so that it is useful for predicting the service life of timber building products. Modern performance-based construction criteria require building products to be characterized in terms of the reliability that they will perform as expected over time. For timber, the current level of understanding of durability is far less developed than for other properties such as structural and fire safety performance, and continued research is required to develop robust service life models (Foliente, 2000). Reliable service life data are also of crucial importance for Life Cycle Assessment (LCA) studies that are used to compare the environmental impacts of wood competing building materials.

Timber performance models have been developed that incorporate climate, durability classification and design factors (Wang et al., 2008b; Viitanen et al., 2010; Brischke and Frühwald Hansson, 2011; Thelandersson et al., 2011), however more data are sought for calibration and fine tuning. As an alternative to using durability class categories to represent wood properties in design guides (MacKenzie et al., 2007), the use of a resistance index and resistance classes has been proposed (Thelandersson et al., 2011). Incorporation of 'durability factors' into a factor method has also been suggested (Dickinson, 2005; ISO 15 686-1, 2000).

Despite the importance of above ground structures in timber engineering, reports of natural durability studies involving above-ground exposures are relatively rare. Numerous laboratory decay tests have been reported, but their relationship with timber performance in service appears limited (Da Costa, 1979; Van Acker et al., 1999). Publications containing in ground 'graveyard' test data are more readily available, but their usefulness for service life modeling of above ground structures is unclear. The need for above ground durability to support performance modeling was more recently recognized, but due to their long duration, many above ground tests are incomplete and yet to be published. Above ground test results are likely to be most heterogeneous as they take a long time to complete and a wider range of standardized and non standardized methods may be used. 
The aims of this review paper were to: (1) survey above-ground natural durability test data from published and ongoing field studies; (2) examine the usefulness of data obtained for service life prediction; and (3) compute resistance factors and consider their implications for understanding the effects of differences between field test sites and methods.

\section{MATERIALS AND METHODS}

\section{MATERIJAL I METODE}

\subsection{Literature survey on above ground durability} test data

2.1. Pregled literature o ispitivanjima trajnosti drva iznad zemlje

Relevant literature was reviewed concerning the natural durability of timber species determined in field tests above ground. Modified and preservative treated timber was not considered as this would be unmanageable, due to increased amount of data and different testing approaches compared to non-treated timbers. Two a priori criteria for articles or data inclusion were set: (1) published in a peer reviewed journal, printed conference proceedings, international standard, project re- port or PhD thesis; (2) a focus on natural durability, field testing or service life.

The reference lists in the articles found and publication lists from durability researchers worldwide were checked for additional articles. The studies which met the a priori criteria used only four different test methods: the horizontal lap-joint test (CEN, 2003; Palanti et al., 2011); the horizontal double layer test (Augusta, 2007; Brischke et al., 2009); the cross brace test (Eslyn et al., 1985; Highley, 1995); and the accelerated L-joint test (Van Acker and Stevens, 2003). The principal configurations of these methods are illustrated in Figure 1. In most cases, there were minor variations in the basic set up for each test method between different studies, for instance in terms of shading, distance to ground, test rig size and material. Untreated control specimens included in tests of treated timber were included if necessary and appropriate.

\subsection{Above ground field tests}

\subsection{Testovi trajnosti drva iznad zemlje}

In addition to published information, data from ongoing tests, which had not been published to date but were accessible to the authors, were included (Tab. 1).

Table 1 Above ground field trials and corresponding literature sources considered for service life related data (Test ID and abbreviations refer to data in Tab. 7 and 8)

Tablica 1. Ispitivanja trajnosti drva iznad zemlje i odgovarajući literaturni izvor za podatke o njegovu životnom vijeku (ID testa i kratice odnose se na podatke u tablicama 7 i 8)

\begin{tabular}{|c|c|c|c|c|c|}
\hline ID & $\begin{array}{c}\text { Test method } \\
\text { Metoda ispitivanja }\end{array}$ & $\begin{array}{c}\text { Abbr. } \\
\text { Kratica }\end{array}$ & $\begin{array}{c}\text { Durability measure } \\
\text { Mjera trajnost } i\end{array}$ & $\begin{array}{l}\text { Reference species } \\
\text { Referentna vrsta }\end{array}$ & $\begin{array}{l}\text { Reference } \\
\text { Referenca }\end{array}$ \\
\hline 1 & Lap-joint test & LpJ & $S L_{\text {mean }}$ & Scots pine sapwood & Original data \\
\hline 2 & Lap-joint test & LpJ & $v_{\text {5years }}$ & Scots pine sapwood & Palanti et al. 2011 \\
\hline 3 & L-joint coated & LJc & $v_{21 \text { years }}$ & Radiata pine sapwood & Original data \\
\hline 4 & L-joint uncoated & $\mathrm{LJu}$ & $v_{21 \text { years }}$ & Radiata pine sapwood & Original data \\
\hline 5 & Accelerated L-joint test & ALJ & $v_{\mathrm{ML}, 4 \text { years }}$ & Scots pine sapwood & Van Acker \& Stevens 2003 \\
\hline 6 & Cross brace test & $\mathrm{CB}$ & $S L_{\text {median }}$ & SYP sapwood $^{1}$ & Highley 1995 \\
\hline 7 & Cross brace test & $\mathrm{CB}$ & $S L_{\text {median }}$ & SYP sapwood $^{1}$ & Highley 1995, Eslyn et al. 1985 \\
\hline 8 & Double layer & $\mathrm{DL}$ & $v_{\text {6years }}$ & Scots pine sapwood & Original data \\
\hline 9 & Double layer & DL & $v_{8 \text { years }}$ & Scots pine sapwood & Original data \\
\hline 10 & Double layer & $\mathrm{DL}$ & $v_{9 \text { years }}$ & Scots pine sapwood & Original data \\
\hline 11 & Double layer & DL & $v_{7 \text { years }}$ & Scots pine sapwood & Brischke et al. 2009 \\
\hline 12 & Double layer & DL & $S L_{\text {mean }}$ & Scots pine sapwood & Original data \\
\hline 13 & Double layer & DL & $S L_{\text {median }}$ & Scots pine sapwood & Original data \\
\hline 14 & Double layer & DL & $v_{\text {6years }}$ & Scots pine sapwood & Original data \\
\hline 15 & Double layer & DL & $v_{7 \text { years }}$ & Scots pine sapwood & Original data \\
\hline 16 & Double layer & $\mathrm{DL}$ & $v_{8 \text { years }}$ & Scots pine sapwood & Original data \\
\hline 17 & Double layer & DL & $S L_{5 \text { th percentile }}$ & Scots pine sapwood & Rapp et al. 2010 \\
\hline 18 & Double layer & $\mathrm{DL}$ & $S L_{25 \text { th percentile }}$ & Scots pine sapwood & Rapp et al. 2010 \\
\hline 19 & Double layer & $\mathrm{DL}$ & $v_{7 \text { years }}$ & Scots pine sapwood & Rapp et al. 2010 \\
\hline 20 & Multi layer, bottom & MLb & $v_{10 \text { years }}$ & Scots pine sapwood & Original data \\
\hline 21 & Multi layer, upper & MLu & $v_{10 \text { years }}$ & Scots pine sapwood & Original data \\
\hline 22 & Bundle test A & $\mathrm{BuA}$ & $v_{4 \text { years }}$ & Scots pine sapwood & Original data \\
\hline 23 & Bundle test B & $\mathrm{BuB}$ & $v_{4 \text { years }}$ & Scots pine sapwood & Original data \\
\hline 24 & Bundle test $\mathrm{C}$ & $\mathrm{BuC}$ & $v_{4 y e a r s}$ & Scots pine sapwood & Original data \\
\hline 25 & Bundle test $\mathrm{D}$ & $\mathrm{BuD}$ & $v_{\text {4years }}$ & Scots pine sapwood & Original data \\
\hline
\end{tabular}

${ }^{1} \mathrm{SYP}=$ Southern Yellow Pine 


\section{L-joint tests in Australia}

Testovi L-spoja u Australiji

Above-ground durability L-joint tests were established in 1987 at different exposure sites in Australia (Francis and Norton 2005, Francis et al. 2007, Wang et al. 2008a). Eight untreated wood species were exposed at 10 field test sites throughout eastern Australia, while an additional 19 untreated wood species were set out at the Beerburrum test site, $65 \mathrm{~km}$ north of Brisbane (Tab. 2 and 3).

L-joint test units were constructed according to Fig. 1d using timber $35 \times 35 \mathrm{~mm}^{2}$ in cross section. Half of the specimens for each species were painted. Each joint was pulled apart after painting to completely break the paint film along the frame of the joint and therefore create a uniformly high decay hazard by allowing moisture to enter and remain in the joint and under the broken paint. The $35 \times 35 \mathrm{~mm}^{2}$ faces at the distal ends of the joint components were sealed with bituminous tape.
At each site L-joints were placed on exposure racks that were constructed using CCA treated plywood and durable framing timbers that are resistant to insect attack. Plastic strips and brackets were fixed to the racks to support L-joints and prevent them from coming into direct contact with each other or the plywood. At all locations the racks were faced north, and they were constructed the way that L-joints placed on them were oriented $10^{\circ}$ backward from vertical to channel moisture toward the joint.

Assessment of the specimens was undertaken after $3,5,7,9,11,16,19$ and 21 years of exposure. Only the $35 \times 35 \times 11 \mathrm{~mm}^{3}$ face of the tenon part of each joint - the component most susceptible to decay - was assessed. The depth and distribution of decay was detected using the pick test, which involves firm probing using a small knife. Decay scores were assigned between 0 (sound, resistant to probing and no apparent loss of structural integrity) and 4 (failure, severe decay through the $11 \times 35 \mathrm{~mm}^{2}$ tenon part of an L-joint) according to Carey et al. (1981).

Table 2 Mean decay rating according to EN 252 (CEN 1989) of specimens exposed in horizontal L-joint tests after 21 years of exposure in Beerburrum, Australia.

Tablica 2. Prosječna ocjena trulosti uzoraka izloženih testu horizontalnog L-spoja prema EN 252 (CEN 1989) nakon 21 godine izlaganja u Beerburrumu, Australija

\begin{tabular}{|c|c|c|c|}
\hline \multirow[t]{2}{*}{$\begin{array}{l}\text { Wood species } \\
\text { Vrsta drva }\end{array}$} & \multirow[t]{2}{*}{$\begin{array}{l}\text { Botanical name } \\
\text { Botanički naziv }\end{array}$} & \multicolumn{2}{|c|}{$\begin{array}{c}\text { Mean decay rating [0-4] } \\
\text { Prosječna ocjena trulosti [0-4] }\end{array}$} \\
\hline & & unpainted / neobojen & painted / obojen \\
\hline Johnstone River hardwood & Backhousia bancroftii & 1.2 & 3.7 \\
\hline Rose alder & Caldcluvia australiensis & 3.7 & 4.0 \\
\hline Northern silky oak & Cardwellia sublimis & 4.0 & 3.8 \\
\hline Spotted gum & Corymbia citriodora $^{1}$ & 2.5 & 3.5 \\
\hline Kapur & Dryobalanops spp. & 1.6 & 3.1 \\
\hline Kamamere & Eucalyptus deglupta & 3.3 & 3.7 \\
\hline Alpine ash & Eucalyptus delegatensis & 3.8 & 3.8 \\
\hline Grey ironbark & Eucalyptus drepanophylla & 0.8 & 2.9 \\
\hline Rose gum & Eucalyptus grandis & 2.2 & 3.0 \\
\hline Messmate & Eucalyptus obliqua & 3.7 & 3.6 \\
\hline Black butt & Eucalyptus pilularis & 2.3 & 2.9 \\
\hline Mountain ash & Eucalyptus regnans & 4.0 & 3.8 \\
\hline Red mahogany & Eucalyptus resinifera & 1.1 & 2.7 \\
\hline Sydney blue gum & Eucalyptus saligna & 2.3 & 2.8 \\
\hline Forest red gum & Eucalyptus teretticorni & 1.2 & 2.6 \\
\hline Queensland maple & Flindersia brayleyana & 3.7 & 4.0 \\
\hline Brush box & Lophostemon confertus & 2.3 & 3.0 \\
\hline Fishtail silky oak & Neorites kevedianus & 1.5 & 3.3 \\
\hline Light red meranti & Shorea spp. & 3.9 & 4.0 \\
\hline Red balau & Shorea spp. & 0.7 & 2.9 \\
\hline White Eungella satinash & Syzygium wesas & 1.9 & 3.1 \\
\hline Hoop pine & Araucaria cunninghammii & 4.0 & 3.4 \\
\hline Black cypress & Callitris endlichrei & 4.0 & 4.0 \\
\hline White cypress & Callitris glaucophylla & 1.8 & 2.2 \\
\hline White cypress sapwood & Callitris glaucophylla & 4.0 & 4.0 \\
\hline Carribean pine & Pinus caribaea & 3.6 & 3.8 \\
\hline Slash pine & Pinus elliottii & 3.9 & 3.9 \\
\hline Radiata pine & Pinus radiata & 4.0 & 3.9 \\
\hline Douglas fir & Pseudotsuga menziesii & 3.9 & 3.9 \\
\hline Western Red Cedar & Thuja plicata & 4.0 & 3.3 \\
\hline
\end{tabular}

${ }^{1}$ Corymbia citriodora subsp. variegata 


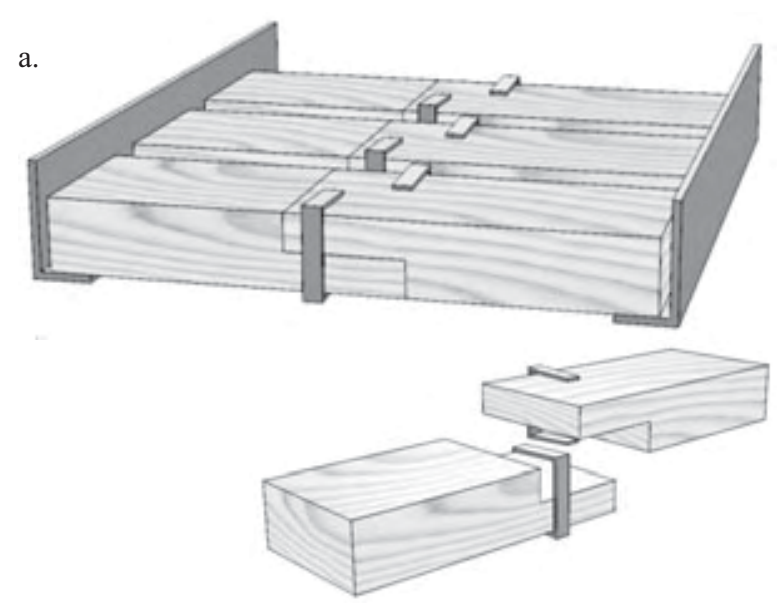

b.

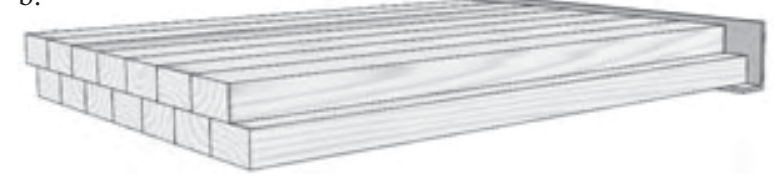

c.

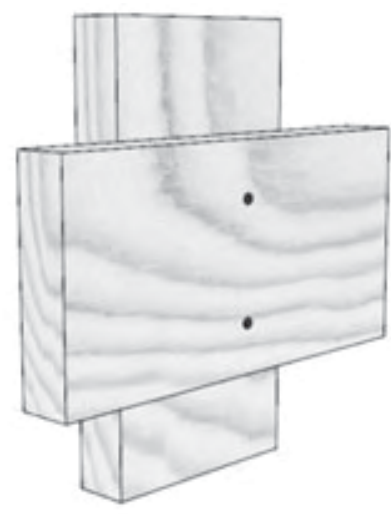

d.
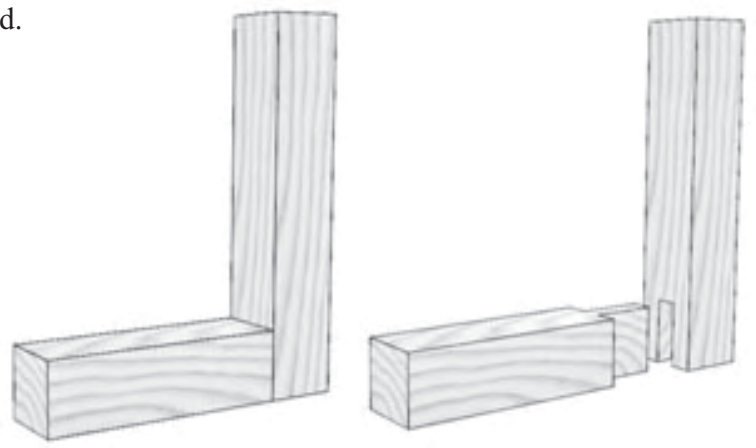

e.

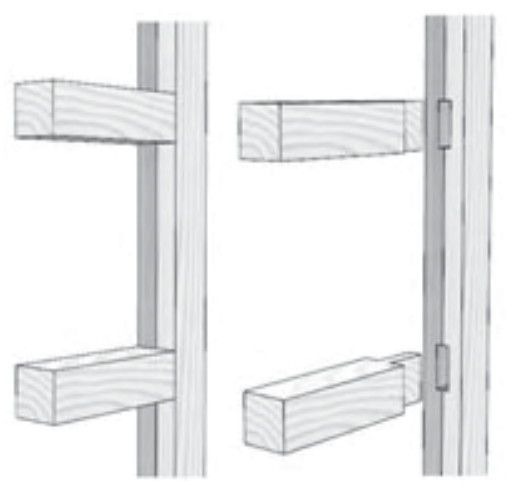

Horizontal lap-joint test

(CEN, 2003)

Horizontalni test lap-spoja

Specimens $\left(38 \times 85 \times 300 \mathrm{~mm}^{3}\right)$ are exposed horizontally on test rigs with supports $1 \mathrm{~m}$ above ground. The two lap-joint segments are fixed through stainless steel clamps or plastic cable strips. The end-grain of each lap-joint is sealed with polyurethane or silicone.

\section{Horizontal double layer test}

Horizontalni test dvostrukog sloja

Specimens $\left(500 \times 50 \times 25 \mathrm{~mm}^{3}\right)$ are exposed horizontally in double layers according to Augusta (2007) with the upper layer displaced laterally by $25 \mathrm{~mm}$ to the lower layer. Supports are $25 \mathrm{~cm}$ above ground and made from aluminum L-profiles or Norway spruce beams with or without a bituminous foil.

Cross brace test - Križni test

Test units are constructed of $19 \times 76.2 \times 152.4 \mathrm{~mm}^{3}$ boards, that are nailed together at their centers to form a cross (e.g. Highley, 1995) and installed on test fences.

\section{L-joint test (CEN, 1993)}

Test L-spoja

Specimens with dimension of $38 \times 38 \mathrm{~mm}^{2}$ in the cross section with a machined mortise and tenon joint are used. The members measure $203 \mathrm{~mm}$ in length. The whole L-joint assembly is either coated and afterwards disassembled or stays uncoated. Different modifications of the standard procedure are also considered.

\section{Accelerated L-joint test \\ Ubrzani test L-spoja}

A modified version of the L-joint test (CEN, 1993) is applied, e.g. according to Van Acker and Stevens (2003). L-joint tenon members are made from the test species. In contrast, the mortise member is half made of beech, and half made of Scots pine sapwood acting as feeder specimen.

Figure 1 Above ground test set ups considered for durability records Slika 1. Testovi trajnosti drva iznad zemlje 


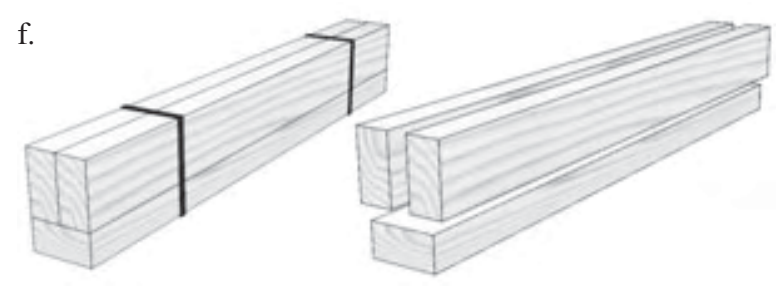

Bundle test Type A

Test svežnja tipa A

Each specimen consists of three segments, which are stakes of $25 \times 50 \times 500 \mathrm{~mm}^{3}$ and are ex-posed as a bundle.

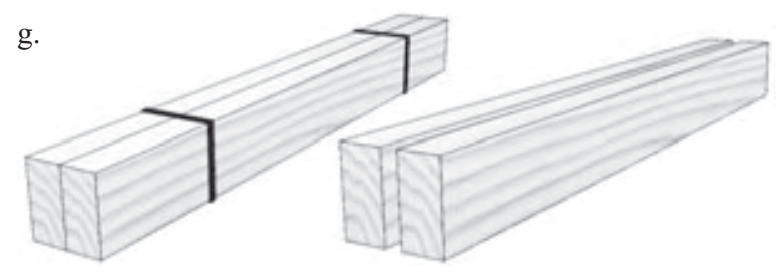

\section{Bundle test Type B}

Test svežnja tipa $B$

Each specimen consists of two segments, which are stakes of $25 \times 50 \times 500 \mathrm{~mm}^{3}$ and are exposed as a bundle.

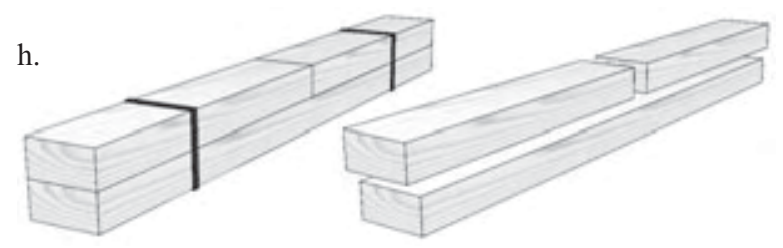

\section{Bundle test Type C}

Test svežnja tipa $C$

Each specimen consists of three segments, one bottom stake of $25 \times 50 \times 500 \mathrm{~mm}^{3}$ and two top stakes of $25 \times 50 \times 250$ $\mathrm{mm}^{3}$, which are exposed as a bundle.

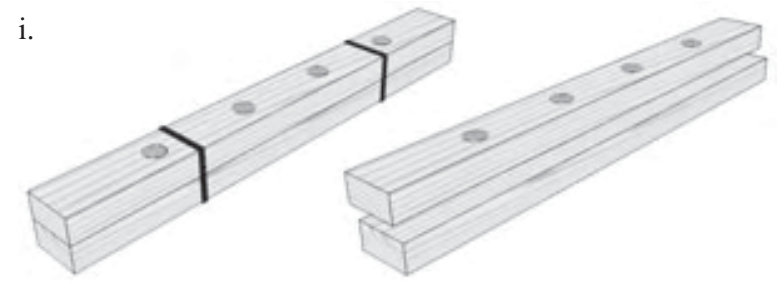

\section{Bundle test Type D}

Test svežnja tipa D

Each specimen consists of two segments, which are stakes of $25 \times 50 \times 500 \mathrm{~mm}^{3}$ and are exposed as a bundle. The upper specimen has four circular drill holes with a diameter of $20 \mathrm{~mm}$ to allow water trapping.

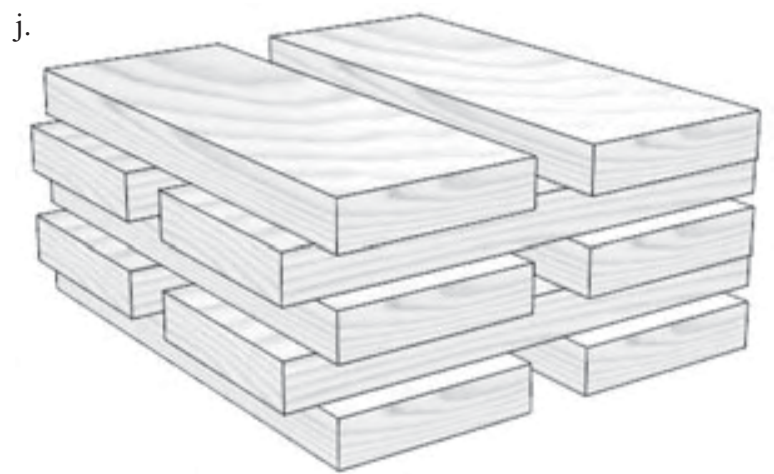

\section{Ground-proximity multiple layer test}

Višeslojni test u blizini zemlje

Each test unit consists of ten specimens of $22 \times 95 \times 250$ $\mathrm{mm}^{3}$, stacked two by two in five crossed layers, bottom layer on the ground, e.g. according to Edlund (2004). To avoid weed growth the ground is covered with a geotextile. Either the two upper boards or the two bottom boards are assessed (indicated as 'upper' and 'bottom').

Figure 1. cont'd: Above ground test set ups considered for durability records.

Slika 1. (nastavak). Testovi trajnosti drva iznad zemlje

\section{Horizontal double layer tests in Europe Horizontalni dvoslojni testovi u Europi}

Double layer tests have been performed at 23 different European test sites to establish dose-response functions for above ground wood decay with wood moisture content (MC) and temperature. A detailed description of the study and a corresponding dose-response performance model is given by Brischke and Rapp (2008a, 2008b, 2010).

Specimens made from Scots pine sapwood (Pinus sylvestris L.) and Douglas fir heartwood (Pseudotsuga menziesii (Mirb.) Franco) were monitored in terms of $\mathrm{MC}$, wood temperature and the progress of fungal decay up to a period of eight years. The specimens $(500 \mathrm{x} 50 \mathrm{x}$ $25 \mathrm{~mm}^{3}$ ), according to EN 252 (CEN 1989), were exposed horizontally in double layer test rigs (see Fig. 1b) producing a decay risk corresponding to European Use Class 3 (CEN 2006). The upper layer was displaced lat- erally by $25 \mathrm{~mm}$ with respect to the lower layer. The lower layer consisted of seven pine sapwood specimens and six Douglas fir specimens; the upper layer consisted of six pine sapwood specimens and five Douglas fir specimens. The whole test set-up formed a closed deck $\left(73 \times 65 \times 21 \mathrm{~cm}^{3}\right)$. The specimens were evaluated yearly through a pick-test using a small knife and rating the extent and distribution of decay according to EN 252 (CEN 1989) as: 0 (sound), 1 (slight attack), 2 (moderate attack), 3 (severe attack) or 4 (failure).

\section{Horizontal double layer tests in Norway Horizontalni dvoslojni testovi u Norveškoj}

Horizontal double layer tests (Fig. 1b) were conducted with 29 different wood species (Tab. 6) as described by Evans et al. (2011) and Flæte et al. (2008, 2011). Specimens were exposed at three different locations in Norway: Oslo (exposed in 2002), Bergen and 
.... Brischke, Meyer, Alfredsen, Humar, Francis, Floete, Larsson-Brelid: Natural Durability...

Table 3 Mean decay rating according to EN 252 (CEN 1989) of specimens exposed in horizontal painted and unpainted L-joint tests after 21 years of exposure at ten different test sites in Australia.

Tablica 3. Prosječna ocjena trulosti obojenih i neobojenih uzoraka izloženih testu horizontalnog L-spoja prema EN 252 (CEN 1989) nakon 21 godine izlaganja na deset različitih mjesta u Australiji

\begin{tabular}{|l|c|c|c|c|c|c|c|c|c|c|c|}
\hline & \multicolumn{7}{|c|}{ Mean decay rating [0-4] / Prosječna ocjena trulosti [0-4] } \\
\cline { 2 - 14 } & $\begin{array}{c}\text { Beer- } \\
\text { burrum }\end{array}$ & Dalby & $\begin{array}{c}\text { Frank- } \\
\text { ston }\end{array}$ & $\begin{array}{c}\text { Pennant } \\
\text { Hills }\end{array}$ & $\begin{array}{c}\text { Rock- } \\
\text { hampton }\end{array}$ & $\begin{array}{c}\text { South } \\
\text { Johnstone }\end{array}$ & $\begin{array}{c}\text { Toow- } \\
\text { oomba }\end{array}$ & $\begin{array}{c}\text { Yarra- } \\
\text { lumba }\end{array}$ & $\begin{array}{c}\text { Mount } \\
\text { Isa }\end{array}$ & $\begin{array}{c}\text { Towns- } \\
\text { ville }\end{array}$ \\
\hline Painted / Obojeno \\
\hline $\mathbf{7}$
\end{tabular}

Ås (exposed in 2004). In Oslo the test site is on the roof of the Norwegian Institute of Wood Technology, an 8 floor building, while the two test sites in Bergen and Ås are on ground level. Test set up and assessment of the specimens were identical with the above described procedure apart from the test rack size, which was larger due to a higher number of tested wood species. Samples were evaluated every year.

\section{Lap-joint and ground-proximity multi layer tests in Sweden \\ Lap-spoj i prizemni višeslojni testovi u Švedskoj}

Horizontal lap-joint tests (Fig. 1a) according to CEN TS 12037 (CEN 2003) and ground-proximity multi layer tests (Fig. 1j) according to Edlund and Jermer (2007) were conducted in Borås, Sweden. Besides different treated timbers, the following untreated control wood species were tested: European larch (Larix decidua Mill.), Siberian larch (Larix sibirica Ledeb.), Norway spruce (Picea abies (L.) H. Karst.), Scots pine (Pinus sylvestris L.), European beech (Fagus sylvatica L.), Aspen (Populus tremula L.), and English oak (Quercus robur L.).

The lap-joint tests were started in 1996 and the specimens were assessed after 5, 8, 10, 12, 13, and 15 years of exposure. The ground-proximity trials were started in 2001 and assessed after 1, 2, 3, 5, and 10 years. Each ground-proximity multi layer test unit consisted of ten specimens, $22 \times 95 \times 250 \mathrm{~mm}^{3}$, that were stacked two by two in five crossed layers, with the bottom layer on the ground. The assessment of the specimens in the stacks was carried out separately for the bottom and the upper part (Tab. 1) using the pick-test. To avoid weed growth around the stacks, the ground had been covered with a geotextile, permeable for micro-organisms.

\section{Bundle tests in Germany \\ Testovi svežnja u Njemačkoj}

Bundle tests of four different types (A-D) after Brischke et al. (2011) were conducted in Northern Germany. The specimens were made from Norway spruce as illustrated in Fig. 1f-i and exposed in 2007. Afterwards they were evaluated annually by using the picktest and rating the extent and distribution of decay according to EN 252 (CEN 1989).

\subsection{Durability measures}

\subsection{Mjere trajnosti}

Numerous evaluation and assessment procedures were analyzed with respect to their significance and informative value for the prediction of service life. The following ranking of preference was applied to the different durability assessment measures:

1. Mean service life of specimens $S L_{\text {mean }}$ (1)

2. Median service life of specimens $S L_{\text {median }}\left(50^{\text {th }}\right.$ percentile, 2)

3. $25^{\text {th }}$ percentile of service life of specimens $S L_{25 \text { th percentile }}$ (3)

4. Decay rate (after $x$ years) $v_{\text {mean }}(4)$

5. $5^{\text {th }}$ percentile of service life of specimens

$S L_{5 \text { th percentile }}(5)$.

$$
S L_{\text {mean }}=\frac{\sum_{i}^{n} S L_{i}}{n}
$$


$S L_{\text {median }} \begin{cases}S L_{\frac{n+1}{2}} & ; \text { if } n \text { is uneven } \\ \frac{1}{2}\left(S L_{\frac{n}{2}}+S L_{\frac{n}{2}+1}\right) & ; \text { if } n \text { is even }\end{cases}$

$S L_{\text {median }} \begin{cases}S L_{\frac{n+1}{4}} & ; \text { if } n \text { is uneven } \\ \frac{1}{2}\left(S L_{\frac{n}{4}}+S L_{\frac{n}{4}+1}\right) & ; \text { if } n \text { is even }\end{cases}$

$v_{\text {mean }}=\frac{\sum_{i}^{n} v_{i}}{n}=\frac{\sum_{i}^{n} \frac{R}{t}}{n}$

$S L_{\text {median }} \begin{cases}S L_{\frac{n+1}{20}} & ; \text { if } n \text { is uneven } \\ \frac{1}{2}\left(S L_{\frac{n}{20}}+S L_{\frac{n}{20}+1}\right) ; \text { if } n \text { is even }\end{cases}$

Where $S L_{i}$ is the service life of a single specimen (the year when a specimen was recorded to have failed) $[\mathrm{y}], v_{i}$ is the decay rate of single specimen $\left[\mathrm{y}^{-1}\right], R$ is the decay rating (score), $t$ is the exposure time [y], and $n$ is the number of replicate specimens.

Decay rate, as represented by the rate of change in decay rating over time, was considered as less desirable quantity with which to determine resistance factors. Whilst decay does not necessarily proceed at a linear rate, it was necessary to consider it as such for the purposes of this study. Different decay rating schemes had been applied, e.g. the five step scales according to EN 252 (CEN, 1989) and EN 330 (CEN, 1993). Alternatively, the decay rate was expressed as 'mass loss rate $v_{\mathrm{ML}}$ ', when only mass loss, but not decay ratings were available (e.g. Van Acker and Stevens, 2003).

\subsection{Resistance factors}

2.4. Čimbenici otpornosti

To make the different durability measures comparable, they were related to the respective reference species and resistance factors $f$ were calculated according to 6 and 7.

$$
\begin{gathered}
f_{S L}=\frac{S L_{\text {tested species }}}{S L_{\text {reference species }}} \\
f_{v}=\frac{v_{\text {reference species }}}{v_{\text {tested species }}}
\end{gathered}
$$

Where $f_{S L}$ and $f_{v}$ are resistance factors based on service life and decay rate (after x years), respectively, $S L$ is the service life $[\mathrm{y}]$, and $v$ is the decay rate $\left[\mathrm{y}^{-1}\right]$. The equation used depended on the durability measure applied for each test: Equation 6 if service life measures were reported or equation 7 if decay ratings were recorded. Resistance factors were calculated for the six species with most available data: spotted gum (Corymbia spp.), oak (Quercus robur/petraea), Norway spruce (Picea abies (L.) H. Karst.), Scots pine (Pinus sylvestris L.), Douglas fir (Pseudotsuga menziesii (Mirb.) Franco), and western red cedar (Thuja plicata Donn ex D. Don).

\section{RESULTS AND DISCUSSION}

\section{REZULTATI I RASPRAVA}

\subsection{Ongoing durability studies}

3.1. Aktualna istraživanja trajnosti

In total, results from six published and five different ongoing durability studies were considered for this survey. To illustrate the latest state of the ongoing studies, which took place at different locations around the world and made use of seven different tests methods, the mean decay ratings are presented for all timber species tested (Fig. 2 and Tab. 2 to 6).

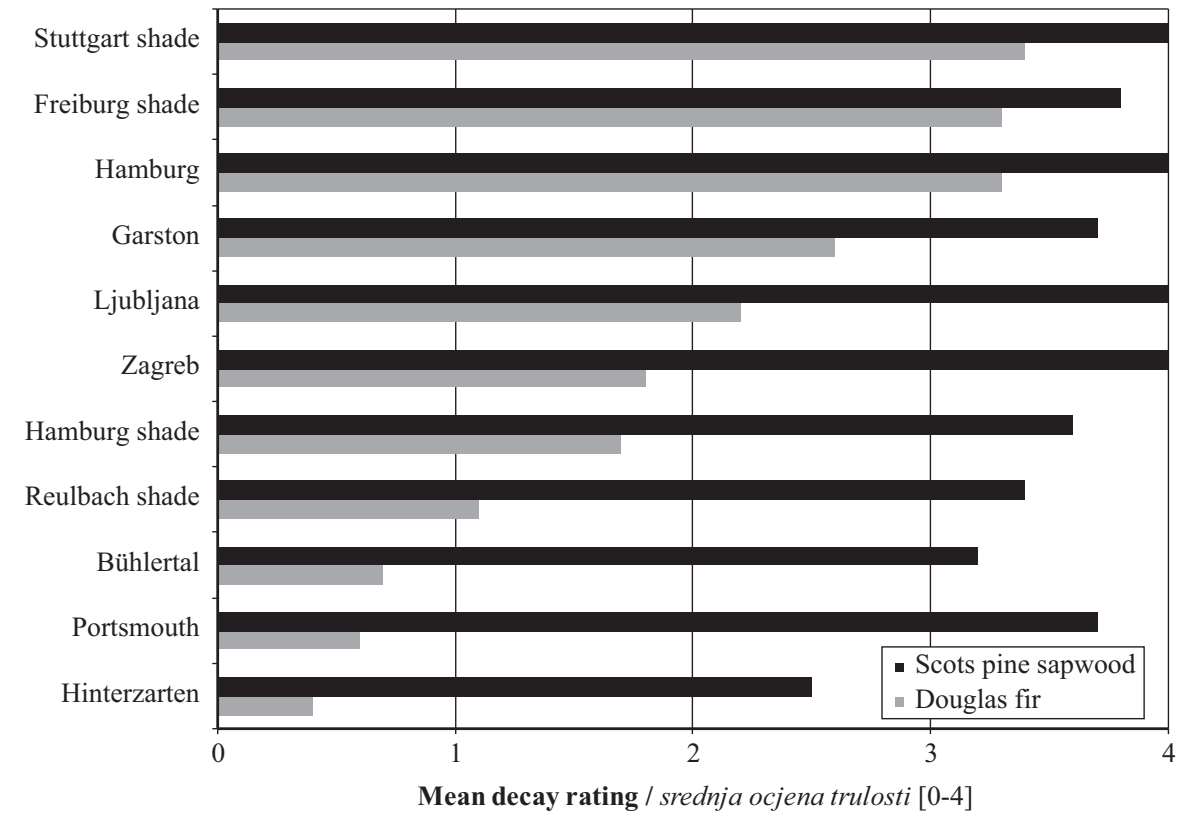

Figure 2 Mean decay rating according to EN 252 (CEN, 1989) of Douglas fir and Scots pine sapwood specimens after 6.5 years exposure in horizontal double layer tests at different locations in Europe.

Slika 2. Prosječna ocjena trulosti uzoraka od bjeljike duglazije i bora izloženih horizontalnome dvoslojnom testu prema EN 252 (CEN 1989) nakon 6,5 godina izlaganja na različitim lokacijama u Europi 
.... Brischke, Meyer, Alfredsen, Humar, Francis, Flaete, Larsson-Brelid: Natural Durability...

Table 4 Mean decay rating according to EN 252 (CEN 1989) of specimens exposed in horizontal lap-joint tests after 12 years of exposure in Borås, Sweden.

Tablica 4. Prosječna ocjena trulosti uzoraka izloženih testu horizontalnog lap-spoja prema EN 252 (CEN 1989) nakon 21 godine izlaganja u Boråsu, Švedska

\begin{tabular}{|c|c|c|c|c|}
\hline \multirow{2}{*}{} & \multicolumn{3}{|c|}{ Mean decay rating [0-4] / Prosječna ocjena trulosti [0-4] } \\
\cline { 2 - 5 } & $\begin{array}{c}\text { Scots pine sapwood } \\
\text { (Pinus sylvestris) }\end{array}$ & $\begin{array}{c}\text { Scots pine heartwood } \\
\text { (Pinus sylvestris) }\end{array}$ & $\begin{array}{c}\text { Norway spruce } \\
\text { (Picea abies) }\end{array}$ & $\begin{array}{c}\text { European larch } \\
\text { (Larix decidua) }\end{array}$ \\
\hline after 5 years & 0.4 & 0.1 & 0.8 & 0.3 \\
\hline after 8 years & 2.7 & 0.5 & 3.4 & 1.5 \\
\hline after 10 years & 3.7 & 2.1 & 3.9 & 2.3 \\
\hline after 12 years & 4.0 & 2.2 & 4.0 & 2.5 \\
\hline after 13 years & - & 2.6 & - & 2.8 \\
\hline after 15 years & - & 2.9 & - & 3.0 \\
\hline
\end{tabular}

Table 5 Mean decay rating according to EN 252 (CEN 1989) of specimens exposed in ground-proximity multi layer tests after 10 years of exposure in Borås, Sweden.

Tablica 5. Prosječna ocjena trulosti uzoraka izloženih prizemnom višeslojnom testu prema EN 252 (CEN 1989) nakon deset godina izlaganja u Boråsu, Švedska

\begin{tabular}{|l|c|c|c|}
\hline Wood species & \multirow{2}{*}{$\begin{array}{c}\text { Botanical name } \\
\text { Vrsta drva }\end{array}$} & Motanički naziv & Boan decay rating [0-4] / Prosječna ocjena trulosti [0-4] \\
\cline { 3 - 4 } & Pinus sylvestris & 4.0 & Upper part / Gornji dio \\
\hline Scots pine sapwood & Pinus sylvestris & 4.0 & 4.0 \\
\hline Scots pine heartwood & Larix decidua & 3.0 & 1.0 \\
\hline European larch & Picea abies & 4.0 & 0.5 \\
\hline Norway spruce & Fagus sylvatica & 2.8 & 4.0 \\
\hline Beech & Quercus robur & 2.5 & 4.0 \\
\hline English oak & Populus tremula & 4.0 & 0.5 \\
\hline Aspen & & 3.3 \\
\hline
\end{tabular}

Table 6 Mean decay rating according to EN 252 (CEN 1989) of specimens exposed in horizontal double layer tests after 6 years of exposure at three test locations in Norway.

Tablica 6. Prosječna ocjena trulosti uzoraka izloženih horizontalnome dvoslojnom testu prema EN 252 (CEN 1989) nakon šest godina izlaganja na tri različite lokacije u Norveškoj

\begin{tabular}{|c|c|c|c|c|}
\hline \multirow{2}{*}{$\begin{array}{l}\text { Wood species } \\
\text { Vrsta drva }\end{array}$} & \multirow{2}{*}{$\begin{array}{l}\text { Botanical name } \\
\text { Botanickki naziv }\end{array}$} & \multicolumn{3}{|c|}{ Mean decay rating [0-4] / Prosječna ocjena trulosti [0-4] } \\
\hline & & Oslo & Ås & Bergen \\
\hline Norway maple & Acer platanoides & - & 1.5 & 3.0 \\
\hline Lime & Tilia cordata & - & 1.5 & 3.2 \\
\hline Aspen & Populus tremula & 2.1 & 1.1 & 2.2 \\
\hline Silver birch / Downy birch & Betula pendula / B. pubescens & 2.1 & 1.5 & 2.0 \\
\hline Alder / Grey alder & Alnus glutinosa & 2.4 & 1.5 & 3.5 \\
\hline Rowan & Sorbus aucuparia & - & 1.2 & 2.0 \\
\hline Goat willow & Salix caprea & - & 0.5 & 2.1 \\
\hline European oak & Quercus spp. & 0.5 & 0.5 & 1.4 \\
\hline Ash & Fraxinus excelsior & - & 0.9 & 1.7 \\
\hline Wych elm & Ulmus glabra & - & 0.5 & 2.0 \\
\hline Beech & Fagus sylvatica & - & 2.0 & 3.1 \\
\hline Cedrela & Cedrela spp. & 0.0 & - & - \\
\hline Sitka spruce & Picea sitchensis & 0.4 & 1.7 & 3.0 \\
\hline Norway spruce $6 \mathrm{~mm}$ rings & Picea abies & - & 2.4 & 2.1 \\
\hline Norway spruce $3 \mathrm{~mm}$ rings & & 2.2 & 2.1 & 1.9 \\
\hline Norway spruce $1 \mathrm{~mm}$ rings & & - & 0.9 & 1.9 \\
\hline Norway spruce standing rings & & - & 1.9 & 2.4 \\
\hline Silver fir & Abies alba & - & 2.9 & 2.9 \\
\hline Scots pine $3 \mathrm{~mm}$ rings & Pinus sylvestris & 0.2 & 1.2 & 1.5 \\
\hline Scots pine $1 \mathrm{~mm}$ rings & & 0.0 & 1.0 & 1.9 \\
\hline Scots pine sapwood & & 2.4 & 1.2 & 2.3 \\
\hline Scots pine sapwood + heartwood & & - & 0.6 & 2.1 \\
\hline Western red cedar (N-America) & Thuja plicata & - & 0.2 & 1.2 \\
\hline Western red cedar (Norway) & & - & 1.3 & 1.4 \\
\hline Juniper & Juniperus communis & - & 0.3 & 0.9 \\
\hline Larch (Russia) & Larix sibirica & 0.4 & 0.9 & 1.4 \\
\hline Larch (Norway) & Larix decidua & - & 0.3 & 1.2 \\
\hline Douglas fir (N-America) & Pseudotsuga menziesii & - & 0.2 & 1.2 \\
\hline
\end{tabular}


Site characteristics were found to affect the performance of particular wood species differently. The mean decay ratings for Douglas fir heartwood after 6.5 years of exposure in horizontal double layer tests at 11 different locations in Europe is shown in Fig. 2 in order descending severity of decay. The respective 'non-durable' reference Scots pine sapwood did not show the same trend for decay severity amongst the 11 test sites. The differing ratio between mean decay rating for Douglas fir and the reference species was presumably caused by a combination of their respective wood properties and climatic differences between sites. The particular properties of each species, such as moisture permeability and potential for leaching of protective extractives, may cause differences in the effects of climatic conditions, such as rainfall and temperature. Similar observations were made for the horizontal double layer samples exposed at three Norwegian test sites (Tab. 6). For instance, the mean decay ratings of grey alder (Alnus glutinosa L.) and Scots pine sapwood were almost the same after 6 years of exposure in Oslo and Ås, whilst the mean decay rating was significantly higher for grey alder in Bergen compared to the Scots pine sapwood reference (Tab. 6). For other species, such as aspen ( $P$. tremula), the ratios between tested timber and reference were nearly the same at all three test locations.

In addition to differences in decay progress between species at climatically different locations, the impact of test methods and test design became apparent. As shown in Tab. 5, the ratio of the mean decay ratings for seven wood species differed significantly between the upper and bottom parts of ground-proximity multi layer tests in Borås, Sweden. The higher moisture load and limited potential for re-drying in the bottom parts of the stack diminished the differences between different timbers, which coincides with the reports by Augusta (2007) and Rapp et al. (2010), who compared the decay development of different European wood species under different exposure conditions above ground. For instance, the good moisture performance of the heartwood of European larch $(L$. decidua), Douglas fir (P. menziesii) or Scots pine (P. sylvestris) is abolished when permanent wetting is provoked. For further comparative analyses of the different above ground trials considered for this survey, resistance factors were considered.

\subsection{Resistance factors}

3.2. Čimbenici otpornosti

The computation of resistance factors allowed the wide range of previous and ongoing tests to be compared, irrespective of test configurations and assessment methods. We found, however, that the number of durability recordings that were freely accessible from publications and relevant for service life prediction was generally sparse. Apart from the fact that above ground durability studies are rare, many of the reported studies contained insufficiently detailed results. The condensed format of presenting test results that is often used for publication inhibited the calculation of resistance factors with sufficiently high statisti- cal reliability. The significance of this problem can be illustrated by considering the Australian L-joint test, which includes 29 different wood species represented by painted and unpainted specimens installed at various locations, and the test has been assessed eight times to date. If the results were reported together, there would be 1808 mean scores alone. It is obviously beyond the scope of one publication to deal with this volume of data, so selected results have been published over time. If only mean scores at a particular time are reported in a single publication, they are not very useful to timber engineers researching service life prediction, as they attempt to find and compile a complete set of data for analysis (Tab. 2 and 3). Furthermore, representative measures of durability may need to be transformed for analysis, for example from ratings (scores) to service life values, so raw data are required. While it is possible to seek data directly from researchers managing durability tests, they may be difficult to find. Individual publications may not reveal the full extent of an entire durability test when only specific elements of data are reported.

Tab. 1 gives an overview of the data regarded for this survey. In total, 163 durability measures from 31 different test sites have been considered for the calculation of resistance factors: 37 for hardwoods and 126 for softwoods. Only three reference species were used to compare the different durability tests: Scots pine sapwood (P. sylvestris), Radiata pine sapwood (Pinus radiata D.Don) and southern yellow pine sapwood ( $P i$ nus spp.). The resistance factors for six selected wood species, for which most durability records were found, are presented in Tab. 7 and 8. Several of these timbers are commonly used untreated for above ground structures that are exposed to the weather, including oak (Quercus spp.), spotted gum (Corymbia spp.) and western red cedar (T. plicata).

Most of the durability recordings were based on preliminary test results, and consequently, decay ratings after 4 to 21 years were used for calculating resistance factors. For most species the range of resistance factors was quite high, for example between 0.90 and 4.54 for Douglas fir (P. menziesii), and in extreme - between 15.88 and 43.03 - for spotted gum (Corymbia spp.). In the case of Douglas fir this can be translated to durability classes (DC, according to EN 350-1, CEN 1994) between DC 5 (non durable) and DC 2 (durable). This variation and how it can be related to at least three, in some cases even to four or five durability classes, is shown for six selected wood species in Fig. 3. The importance of this variation becomes even more obvious when calculating the expected service life: Based on a mean service life of 6.5 years of the Scots pine sapwood reference (Tab. 8), the service life to be expected for Douglas fir ranges from 7.4 to 29.5 years. Even more drastic is the range for spotted gum (Corymbia spp.), which is from 18.7 years and 473.3 years. These findings highlight the potential value of service life modeling to greatly increase the accuracy and relevance of information available regarding the expected durability of timber used at different locations. 
.... Brischke, Meyer, Alfredsen, Humar, Francis, Flaete, Larsson-Brelid: Natural Durability...

Table 7 Service life related data from above-ground field tests according to Tab. 1 Hardwoods.

Tablica 7. Podaci o životnom vijeku povezani s testovima izloženosti drva iznad zemlje prema tablici 1. za tvrde vrste drva

\begin{tabular}{|c|c|c|c|c|c|c|c|}
\hline $\begin{array}{c}\text { Wood species } \\
\text { Vrsta drva }\end{array}$ & $\begin{array}{l}\text { Botanical name } \\
\text { Botanički naziv }\end{array}$ & Site / Mjesto & $\begin{array}{l}\text { Country code } \\
\text { Kod zemlje }\end{array}$ & $\begin{array}{c}\text { Test method } \\
\text { Metoda }\end{array}$ & $\begin{array}{l}\text { Test } \\
\text { ID }\end{array}$ & $\begin{array}{c}\text { Resistance } \\
\text { factor } \\
\text { Faktor otpora }\end{array}$ & $\boldsymbol{S} \boldsymbol{L}_{\text {Reference }}{ }^{1}$ \\
\hline \multirow[t]{22}{*}{ Spotted gum } & \multirow[t]{22}{*}{ Corymbia citriodora } & \multirow{4}{*}{ Beerburrum } & \multirow{4}{*}{ AUS } & $\mathrm{LJu}$ & 4 & 12.40 & 5.1 \\
\hline & & & & & 4 & 4.62 & 8.5 \\
\hline & & & & LJc & 3 & 7.23 & 3.7 \\
\hline & & & & & 3 & 3.68 & 5.0 \\
\hline & & \multirow{2}{*}{ Dalby } & \multirow{2}{*}{ AUS } & $\mathrm{LJu}$ & 4 & 9.02 & 6.8 \\
\hline & & & & LJc & 3 & 7.00 & 4.1 \\
\hline & & \multirow{2}{*}{ Frankston } & \multirow{2}{*}{ AUS } & $\mathrm{LJu}$ & 4 & 7.39 & 7.4 \\
\hline & & & & LJc & 3 & 4.24 & 7.0 \\
\hline & & \multirow{2}{*}{ Pennant Hills } & \multirow{2}{*}{ AUS } & LJu & 4 & 4.87 & 7.9 \\
\hline & & & & LJc & 3 & 2.56 & 7.3 \\
\hline & & \multirow{2}{*}{ Rockhampton } & \multirow{2}{*}{ AUS } & LJu & 4 & 16.34 & 7.7 \\
\hline & & & & LJc & 3 & 4.98 & 5.2 \\
\hline & & \multirow{2}{*}{ South Johnstone } & \multirow{2}{*}{ AUS } & $\mathrm{LJu}$ & 4 & 3.49 & 5.7 \\
\hline & & & & LJc & 3 & 5.23 & 5.1 \\
\hline & & \multirow{2}{*}{ Toowoomba } & \multirow{2}{*}{ AUS } & LJu & 4 & 20.69 & 6.8 \\
\hline & & & & LJc & 3 & 8.51 & 3.4 \\
\hline & & \multirow{2}{*}{ Yarralumla } & \multirow{2}{*}{ AUS } & LJu & 4 & 31.61 & 8.7 \\
\hline & & & & LJc & 3 & 3.48 & 7.0 \\
\hline & & \multirow{2}{*}{ Mount Isa } & \multirow{2}{*}{ AUS } & $\mathrm{LJu}$ & 4 & 43.03 & 11.0 \\
\hline & & & & LJc & 3 & 15.88 & 11.0 \\
\hline & & \multirow{2}{*}{ Townsville } & \multirow{2}{*}{ AUS } & LJu & 4 & 6.43 & 5.3 \\
\hline & & & & LJc & 3 & 2.06 & 5.0 \\
\hline \multirow[t]{9}{*}{ English oak } & \multirow[t]{9}{*}{ Quercus robur } & Hamburg & $\mathrm{D}$ & DL & 11 & 1.56 & 6.5 \\
\hline & & Hamburg shade & $\mathrm{D}$ & DL & 11 & 1.35 & 6.1 \\
\hline & & Reulbach & $\mathrm{D}$ & DL & 11 & 1.83 & n.a. \\
\hline & & Stuttgart & $\mathrm{D}$ & DL & 11 & 1.66 & n.a. \\
\hline & & Freiburg & $\mathrm{D}$ & DL & 11 & 1.52 & n.a. \\
\hline & & 4 German sites & $\mathrm{D}$ & DL & 17 & 1.70 & 6.6 \\
\hline & & Ghent & $\mathrm{B}$ & ALJ & 5 & 5.67 & n.a. \\
\hline & & \multirow{2}{*}{ Borås } & \multirow{2}{*}{$\mathrm{S}$} & $\mathrm{MLu}$ & 21 & 4.00 & 10.0 \\
\hline & & & & MLb & 20 & 1.33 & 10.0 \\
\hline \multirow[t]{3}{*}{ European oak } & \multirow[t]{3}{*}{ Q. robur/Q. petraea } & Ås & $\mathrm{N}$ & DL & 8 & 2.50 & n.a. \\
\hline & & Oslo & $\mathrm{N}$ & DL & 9 & 3.00 & 8.0 \\
\hline & & Bergen & $\mathrm{N}$ & DL & 8 & 1.67 & n.a. \\
\hline
\end{tabular}

${ }^{1}$ mean value or median (in italics) / srednja vrijednost ili medijan (u kurzivu); n.a. = not available / nije dostupno

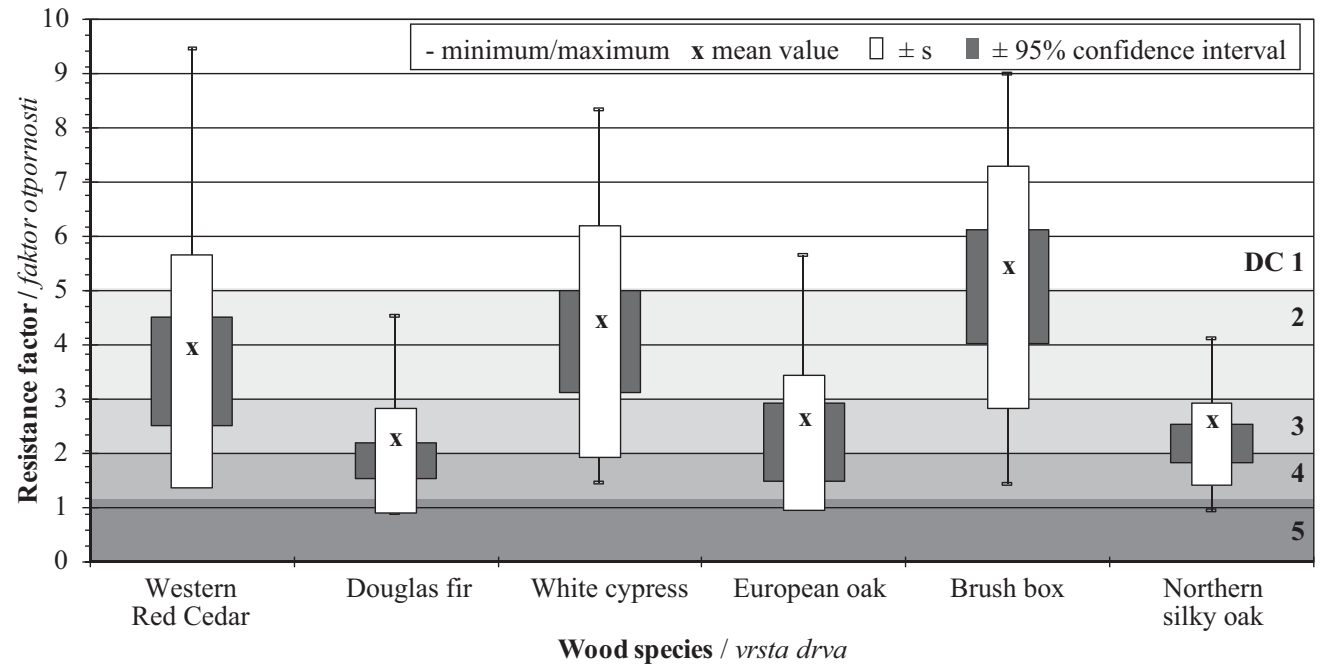

Figure 3 Variation of resistance factors of six selected wood species and corresponding durability classes (DC) according to EN 350-1 (CEN, 1994).

Slika 3. Varijacija čimbenika otpornosti za šest različitih vrsta drva i odgovarajuće klase trajnosti prema EN 350-1 (CEN, 1994). 
Table 8 Service life related data from above-ground field tests according to Tab. 1 Softwoods.

Tablica 8. Podaci o životnom vijeku povezani s testovima izloženosti drva iznad zemlje prema tablici 1. za meke vrste drva

\begin{tabular}{|c|c|c|c|c|c|c|c|}
\hline $\begin{array}{l}\text { Wood species } \\
\text { Vrsta drva }\end{array}$ & $\begin{array}{l}\text { Botanical name } \\
\text { Botanički naziv }\end{array}$ & Site / Mjesto & $\begin{array}{c}\text { Country } \\
\text { code } \\
\text { Kod zemlje }\end{array}$ & $\begin{array}{c}\text { Test } \\
\text { method } \\
\text { Metoda }\end{array}$ & $\begin{array}{l}\text { Test } \\
\text { ID }\end{array}$ & $\begin{array}{c}\begin{array}{c}\text { Resistance } \\
\text { factor } \\
\text { Faktor otpora }\end{array} \\
\end{array}$ & $\boldsymbol{S} \boldsymbol{L}_{\text {Reference }}{ }^{1}$ \\
\hline \multirow{4}{*}{ Norway spruce heart } & \multirow{4}{*}{ Picea abies } & Hamburg & $\mathrm{D}$ & $\mathrm{DL}$ & 19 & 0.96 & 6.5 \\
\hline & & Hamburg shade & $\mathrm{D}$ & $\mathrm{DL}$ & 19 & 0.78 & 6.1 \\
\hline & & Stuttgart & $\mathrm{D}$ & $\mathrm{DL}$ & 19 & 0.89 & n.a. \\
\hline & & Freiburg & $\mathrm{D}$ & $\mathrm{DL}$ & 19 & 0.75 & n.a. \\
\hline \multirow[t]{9}{*}{ Norway spruce } & \multirow[t]{9}{*}{ Picea abies } & Oslo & $\mathrm{N}$ & $\mathrm{DL}$ & 9 & 1.19 & 8.0 \\
\hline & & \multirow[t]{4}{*}{ Hannover } & \multirow[t]{4}{*}{$\mathrm{D}$} & $\mathrm{BuA}$ & 22 & 0.82 & 4.0 \\
\hline & & & & $\mathrm{BuB}$ & 23 & 0.92 & n.a \\
\hline & & & & $\mathrm{BuC}$ & 24 & 0.96 & n.a. \\
\hline & & & & $\mathrm{BuD}$ & 25 & 1.00 & 4.0 \\
\hline & & \multirow[t]{3}{*}{ Borås } & \multirow[t]{3}{*}{$\mathrm{S}$} & $\mathrm{LpJ}$ & 1 & 1.00 & 8.0 \\
\hline & & & & $\mathrm{MLu}$ & 21 & 1.00 & 10.0 \\
\hline & & & & MLb & 20 & 1.00 & 10.0 \\
\hline & & Ghent & $\mathrm{B}$ & ALJ & 5 & 2.16 & n.a. \\
\hline \multirow{2}{*}{$\begin{array}{l}\text { Norway spruce, } 6 \mathrm{~mm} \\
\text { rings }\end{array}$} & Picea abies & Ås & $\mathrm{N}$ & $\mathrm{DL}$ & 8 & 0.48 & n.a. \\
\hline & & Bergen & $\mathrm{N}$ & $\mathrm{DL}$ & 8 & 1.11 & n.a. \\
\hline \multirow{2}{*}{$\begin{array}{l}\text { Norway spruce, } \\
3 \mathrm{~mm} \text { rings }\end{array}$} & \multirow[t]{2}{*}{ Picea abies } & Ås & $\mathrm{N}$ & $\mathrm{DL}$ & 8 & 0.56 & n.a. \\
\hline & & Bergen & $\mathrm{N}$ & $\mathrm{DL}$ & 8 & 1.20 & n.a. \\
\hline \multirow{2}{*}{$\begin{array}{l}\text { Norway spruce, } 1 \mathrm{~mm} \\
\text { rings }\end{array}$} & \multirow[t]{2}{*}{ Picea abies } & Ås & $\mathrm{N}$ & $\mathrm{DL}$ & 8 & 1.36 & n.a. \\
\hline & & Bergen & $\mathrm{N}$ & $\mathrm{DL}$ & 8 & 1.25 & n.a. \\
\hline \multirow{2}{*}{$\begin{array}{l}\text { Norway spruce, standing } \\
\text { rings }\end{array}$} & \multirow[t]{2}{*}{ Picea abies } & Ås & $\mathrm{N}$ & $\mathrm{DL}$ & 8 & 1.00 & n.a. \\
\hline & & Bergen & $\mathrm{N}$ & $\mathrm{DL}$ & 8 & 0.94 & n.a. \\
\hline \multirow[t]{4}{*}{ Norway spruce sap } & \multirow[t]{4}{*}{ Picea abies } & Hamburg & $\mathrm{D}$ & $\mathrm{DL}$ & 19 & 0.79 & 6.5 \\
\hline & & Hamburg shade & $\mathrm{D}$ & DL & 19 & 0.98 & 6.1 \\
\hline & & Stuttgart & $\mathrm{D}$ & $\mathrm{DL}$ & 19 & 0.67 & n.a. \\
\hline & & Freiburg & $\mathrm{D}$ & $\mathrm{DL}$ & 19 & 0.45 & n.a. \\
\hline \multirow[t]{7}{*}{ Scots pine } & Pinus sylvestris & 4 German sites & $\mathrm{D}$ & $\mathrm{DL}$ & 18 & 1.34 & 6.6 \\
\hline & & Ghent & $\mathrm{B}$ & ALJ & 5 & 9.31 & n.a. \\
\hline & & Hamburg & $\mathrm{D}$ & $\mathrm{DL}$ & 10 & 1.37 & 6.4 \\
\hline & & Hamburg shade & $\mathrm{D}$ & $\mathrm{DL}$ & 10 & 1.18 & 7.8 \\
\hline & & Borås & $\mathrm{S}$ & LpJ & 1 & 1.25 & 8.0 \\
\hline & & & & MLu & 21 & 4.00 & 10.0 \\
\hline & & & & MLb & 20 & 1.00 & 10.0 \\
\hline Scots pine resinous & Pinus sylvestris & Borås & $\mathrm{S}$ & $\mathrm{MLu}$ & 21 & 4.00 & 10.0 \\
\hline & & & & MLb & 20 & 1.14 & 10.0 \\
\hline Scots pine, slow grown & Pinus sylvestris & Oslo & $\mathrm{N}$ & DL & 9 & 3.79 & 8.0 \\
\hline Scots pine, normal & Pinus sylvestris & Oslo & $\mathrm{N}$ & $\mathrm{DL}$ & 9 & 3.27 & 8.0 \\
\hline Scots pine, $3 \mathrm{~mm}$ rings & Pinus sylvestris & Ås & $\mathrm{N}$ & $\mathrm{DL}$ & 8 & 1.00 & n.a. \\
\hline & & Bergen & $\mathrm{N}$ & $\mathrm{DL}$ & 8 & 1.50 & n.a. \\
\hline Scots pine, $1 \mathrm{~mm}$ rings & Pinus sylvestris & Ås & $\mathrm{N}$ & DL & 8 & 1.15 & n.a. \\
\hline & & Bergen & $\mathrm{N}$ & $\mathrm{DL}$ & 8 & 1.25 & n.a. \\
\hline Scots pine heart + sap & Pinus sylvestris & Ås & $\mathrm{N}$ & DL & 8 & 1.07 & n.a. \\
\hline & & Bergen & $\mathrm{N}$ & DL & 8 & 1.11 & n.a. \\
\hline Douglas fir & Pseudotsuga & 4 German sites & $\mathrm{D}$ & $\mathrm{DL}$ & 18 & 1.45 & 6.6 \\
\hline & menziesii & Hamburg & $\mathrm{D}$ & DL & 12 & 1.25 & 6.5 \\
\hline & & Hamburg shade & $\mathrm{D}$ & DL & 16 & 2.14 & 7.1 \\
\hline & & Hamburg & $\mathrm{D}$ & $\mathrm{DL}$ & 10 & 4.17 & 6.4 \\
\hline & & Hamburg shade & $\mathrm{D}$ & DL & 10 & 2.12 & 7.8 \\
\hline & & Stuttgart shade & $\mathrm{D}$ & $\mathrm{DL}$ & 13 & 1.22 & 6.0 \\
\hline & & Freiburg shade & $\mathrm{D}$ & $\mathrm{DL}$ & 13 & 1.08 & 7.3 \\
\hline & & Reulbach shade & $\mathrm{D}$ & $\mathrm{DL}$ & 13 & 2.50 & 8.1 \\
\hline & & Hinterzarten & $\mathrm{D}$ & $\mathrm{DL}$ & 16 & 3.18 & n.a. \\
\hline & & Bühlertal & $\mathrm{D}$ & $\mathrm{DL}$ & 16 & 3.98 & 7.7 \\
\hline & & Garston & GB & DL & 14 & 1.63 & 6.1 \\
\hline
\end{tabular}


Brischke, Meyer, Alfredsen, Humar, Francis, Floete, Larsson-Brelid: Natural Durability...

Table 8 cont'd: Service life related data from above-ground field tests according to Tab. 1 Softwoods.

Tablica 8. (nastavak) Podaci o životnom vijeku povezani s testovima izloženosti drva iznad zemlje prema tablici 1. za meke vrste drva

\begin{tabular}{|c|c|c|c|c|c|c|c|}
\hline $\begin{array}{l}\text { Wood species } \\
\text { Vrsta drva }\end{array}$ & $\begin{array}{l}\text { Botanical name } \\
\text { Botanički naziv }\end{array}$ & Site / Mjesto & $\begin{array}{c}\text { Country } \\
\text { code } \\
\text { Kod zemlje }\end{array}$ & $\begin{array}{c}\text { Test } \\
\text { method } \\
\text { Metoda }\end{array}$ & $\begin{array}{l}\text { Test } \\
\text { ID }\end{array}$ & $\begin{array}{c}\text { Resistance } \\
\text { factor } \\
\text { Faktor otpora }\end{array}$ & $\boldsymbol{S} \boldsymbol{L}_{\text {Reference }}{ }^{1}$ \\
\hline & & Portsmouth & GB & DL & 15 & 4.54 & 6.0 \\
\hline & & \begin{tabular}{|l|} 
Ljubljana \\
\end{tabular} & SI & $\mathrm{DL}$ & 16 & 3.31 & 3.2 \\
\hline & & Zagreb & HR & DL & 14 & 3.38 & 4.3 \\
\hline & & \begin{tabular}{|l|} 
Madison, WI \\
\end{tabular} & USA & $\mathrm{CB}$ & 6 & $>2.31^{2}$ & 13.0 \\
\hline & & Starkville, MI & USA & $\mathrm{CB}$ & 7 & $>2.00^{2}$ & 10.0 \\
\hline & & \multirow[t]{2}{*}{ Beerburrum } & \multirow[t]{2}{*}{ AUS } & $\mathrm{LJu}$ & 4 & 1.74 & 5.1 \\
\hline & & & & LJc & 3 & 1.12 & 3.7 \\
\hline & & \multirow[t]{2}{*}{ Dalby } & \multirow[t]{2}{*}{ AUS } & $\mathrm{LJu}$ & 4 & 1.29 & 6.8 \\
\hline & & & & LJc & 3 & 1.28 & 4.1 \\
\hline & & \multirow[t]{2}{*}{ Frankston } & \multirow[t]{2}{*}{ AUS } & $\mathrm{LJu}$ & 4 & 1.40 & 7.4 \\
\hline & & & & LJc & 3 & 1.39 & 7.0 \\
\hline & & \multirow[t]{2}{*}{ Pennant Hills } & \multirow[t]{2}{*}{ AUS } & $\mathrm{LJu}$ & 4 & 1.34 & 7.9 \\
\hline & & & & LJc & 3 & 1.36 & 7.3 \\
\hline & & \multirow[t]{2}{*}{ Rockhampton } & \multirow[t]{2}{*}{ AUS } & $\mathrm{LJu}$ & 4 & 1.20 & 7.7 \\
\hline & & & & LJc & 3 & 1.16 & 5.2 \\
\hline & & \multirow[t]{2}{*}{ South Johnstone } & \multirow[t]{2}{*}{ AUS } & $\mathrm{LJu}$ & 4 & 0.96 & 5.7 \\
\hline & & & & LJc & 3 & 1.17 & 5.1 \\
\hline & & \multirow[t]{2}{*}{ Toowoomba } & AUS & $\mathrm{LJu}$ & 4 & 1.14 & 6.8 \\
\hline & & & & LJc & 3 & 1.43 & 3.4 \\
\hline & & \multirow[t]{2}{*}{ Yarralumla } & AUS & $\mathrm{LJu}$ & 4 & 1.33 & 8.7 \\
\hline & & & & LJc & 3 & 1.58 & 7.0 \\
\hline & & \multirow[t]{2}{*}{ Mount Isa } & \multirow[t]{2}{*}{ AUS } & $\mathrm{LJu}$ & 4 & 0.90 & n.a. \\
\hline & & & & LJc & 3 & 1.79 & 11.0 \\
\hline & & \multirow[t]{2}{*}{ Townsville } & \multirow[t]{2}{*}{ AUS } & $\mathrm{LJu}$ & 4 & 1.28 & 11.0 \\
\hline & & & & LJc & 3 & 1.95 & 5.3 \\
\hline Douglas fir (Norway) & $\begin{array}{l}\text { Pseudotsuga } \\
\text { menziesii }\end{array}$ & Bergen & $\mathrm{N}$ & $\mathrm{DL}$ & 8 & 1.88 & n.a. \\
\hline Douglas fir (N-America) & $\begin{array}{l}\text { Pseudotsuga } \\
\text { menziesii }\end{array}$ & Bergen & $\mathrm{N}$ & DL & 8 & 2.31 & n.a. \\
\hline \multirow[t]{19}{*}{ Western Red Cedar } & Thuja plicata & Madison, WI & USA & $\mathrm{CB}$ & 6 & $>2.30^{2}$ & 13.0 \\
\hline & & Beerburrum & AUS & $\mathrm{LJu}$ & 4 & 3.03 & 5.1 \\
\hline & & & & LJc & 3 & 4.53 & 3.7 \\
\hline & & Dalby & AUS & $\mathrm{LJu}$ & 4 & 3.54 & 6.8 \\
\hline & & & & LJc & 3 & 7.97 & 4.1 \\
\hline & & Frankston & AUS & $\mathrm{LJu}$ & 4 & 3.04 & 7.4 \\
\hline & & & & LJc & 3 & 2.22 & 7.0 \\
\hline & & Pennant Hills & AUS & $\mathrm{LJu}$ & 4 & 1.98 & 7.9 \\
\hline & & & & LJc & 3 & 2.06 & 7.3 \\
\hline & & Rockhampton & AUS & $\mathrm{LJu}$ & 4 & 2.93 & 7.7 \\
\hline & & & & LJc & 3 & 3.59 & 5.2 \\
\hline & & South Johnstone & AUS & $\mathrm{LJu}$ & 4 & 2.19 & 5.7 \\
\hline & & & & LJc & 3 & 1.97 & 5.1 \\
\hline & & Toowoomba & AUS & $\mathrm{LJu}$ & 4 & 2.14 & 6.8 \\
\hline & & & & LJc & 3 & 9.48 & 3.4 \\
\hline & & Yarralumla & AUS & $\mathrm{LJu}$ & 4 & 2.00 & 8.7 \\
\hline & & & & LJc & 3 & 3.68 & 7.0 \\
\hline & & Mount Isa & AUS & $\mathrm{LJu}$ & 4 & 1.52 & n.a. \\
\hline & & & & LJc & 3 & 3.44 & 11.0 \\
\hline Western Red Cedar & Thuja plicata & Townsville & AUS & $\mathrm{LJu}$ & 4 & 2.23 & 11.0 \\
\hline & & & & LJc & 3 & 6.69 & 5.3 \\
\hline WRC (Norway) & Thuja plicata & Ås & $\mathrm{N}$ & $\mathrm{DL}$ & 8 & $\mathbf{0 . 8 8}$ & n.a. \\
\hline & & Bergen & $\mathrm{N}$ & DL & 8 & 1.67 & n.a. \\
\hline WRC (N-America) & Thuja plicata & Bergen & $\mathrm{N}$ & DL & 8 & 2.00 & n.a. \\
\hline
\end{tabular}

${ }^{1}$ mean value or median (in italics) / srednja vrijednost ili medijan (u kurzivu)

${ }^{2}$ based on estimated median service life / utemeljeno na procjeni medijana životnog vijeka

n.a. = not available / nije dostupno 
Although most of the results are still preliminary, they indicate that the resistance factor, and hence the relative durability of different species, is not necessarily the same at climatically different places. This is confirmed by the results for European oak (Quercus robur / Quercus petraea): While the resistance factors for eight German test sites differed only between 1.35 and 1.83, a variation between 1.67 and 3.00 was found for three Norwegian sites. As there were only a few species for which multiple recordings were available, no clear relationship between the test site and resulting relative durability was discernible. Significantly more durability recordings from different sites are needed. As previously discussed, chemical and anatomical properties of different species may influence the extent to which they are affected by climate variables, and this topic requires further investigation.

Another example is illustrated in Fig. 4, where the resistance factors of eight wood species determined in L-joint tests have been compared between ten test sites in Australia. Many additional wood species were installed at the Beerburrum site, while only nine wood species were installed at all ten sites. It would be ideal if resistance factors for the nine species tested at all sites could be used to gauge the performance of the additional species at Beerburrum, if they were used at the other locations. No simple relationship between relative resistance factors and test location was observed that represented all species. The higher the resistance factor - and thus the expected service life - the higher was the site-specific variation. In extreme, the factors differed between 4 and 32. For those wood species, showing resistance factors below 5 , which is equivalent to durability class 2 = 'durable' according to EN 350-1 (CEN, 1994), the variation between most of the sites diminished, while differences between sites for the species with higher resistance factors showed the opposite. The test sites represent a wide range of climatic conditions, and preliminary analysis revealed that there is a strong relationship between climate variables and relative durability of each wood species exposed at different locations (Francis and Norton, 2006). The influence of the analyzed climate variables differed amongst the eight species. Further research is required to explore the possibility of using resistance factors to predict durability between different locations based on indicating wood species that are selected to represent groups of wood species with similar properties. For example, the resistance factors for spotted gum may more accurately predict the service life of dense hardwoods that contain extractives that are highly toxic to decay fungi, while resistance factors for brush box may be used to predict the service life of dense hardwoods that contain moderately toxic extractives.

To further examine the potential relationship between the severity of a test site and respective durability of timber species, resistance factors were correlated with the service life (mean or median) of the reference wood species for all sites at which these data were available. As shown exemplarily for three softwoods and three hardwoods in Fig. 5, no clear relationship was obtained. It leads to the conclusion that other factors than the site-specific decay intensity determine the relative resistance, such as climatic peculiarities, different decay types, or detoxifying agents.

In addition to potential site-specific effects, the test method and especially the durability measure seem to influence the resistance factors. While no clear differences between the use of mean or median service lives on the one hand and decay rates after certain exposure times on the other hand were observed, the use of mass loss differences led to significant outliers for

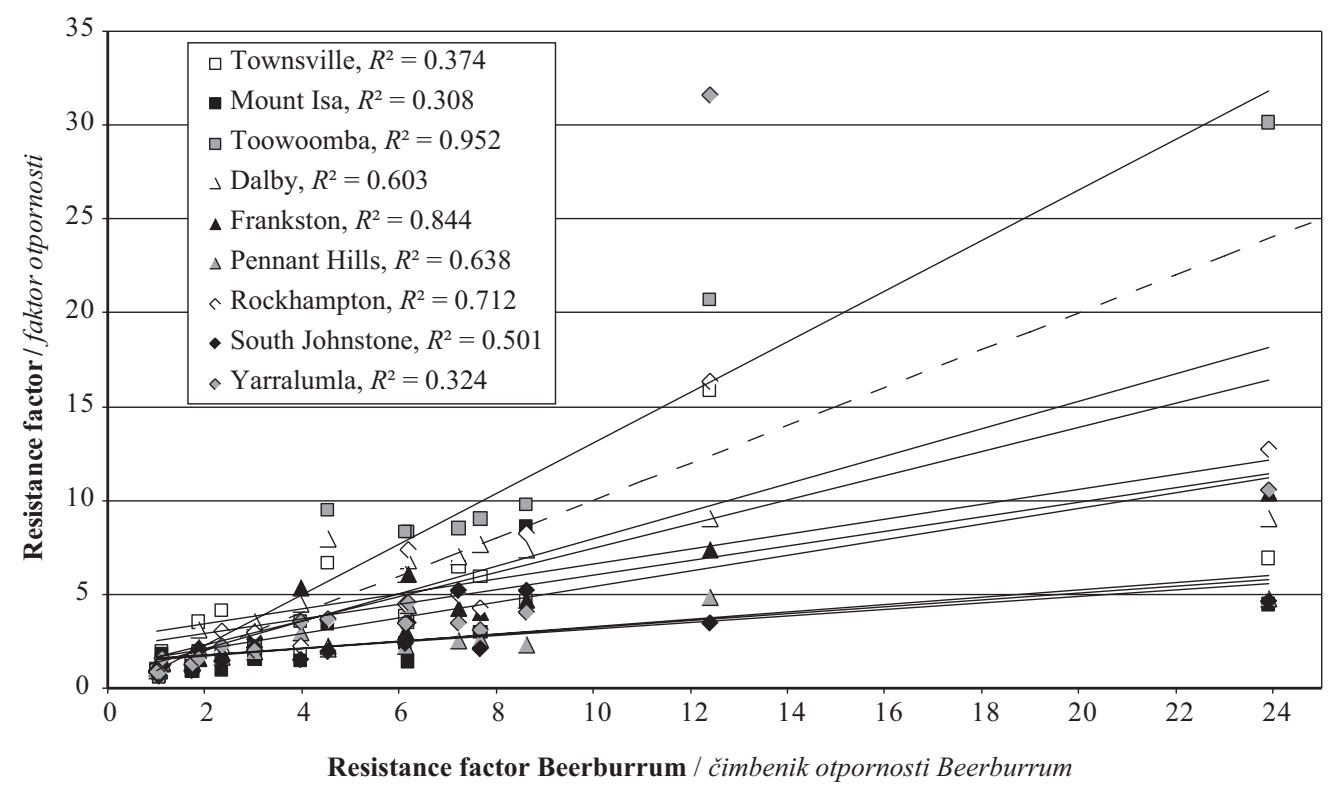

Figure 4 Relationship between resistance factors of eight wood species determined in L-joint trials for ten Australian test sites. Dashed line refers to resistance factors determined for Beerburrum (ideal line).

Slika 4. Odnos između čimbenika otpornosti za osam vrsta drva određenih testom L-spoja za deset lokacija u Australiji. Isprekidana se linija odnosi na čimbenike otpornosti određene za Beerburrum (idealna linija). 
.... Brischke, Meyer, Alfredsen, Humar, Francis, Flaete, Larsson-Brelid: Natural Durability...

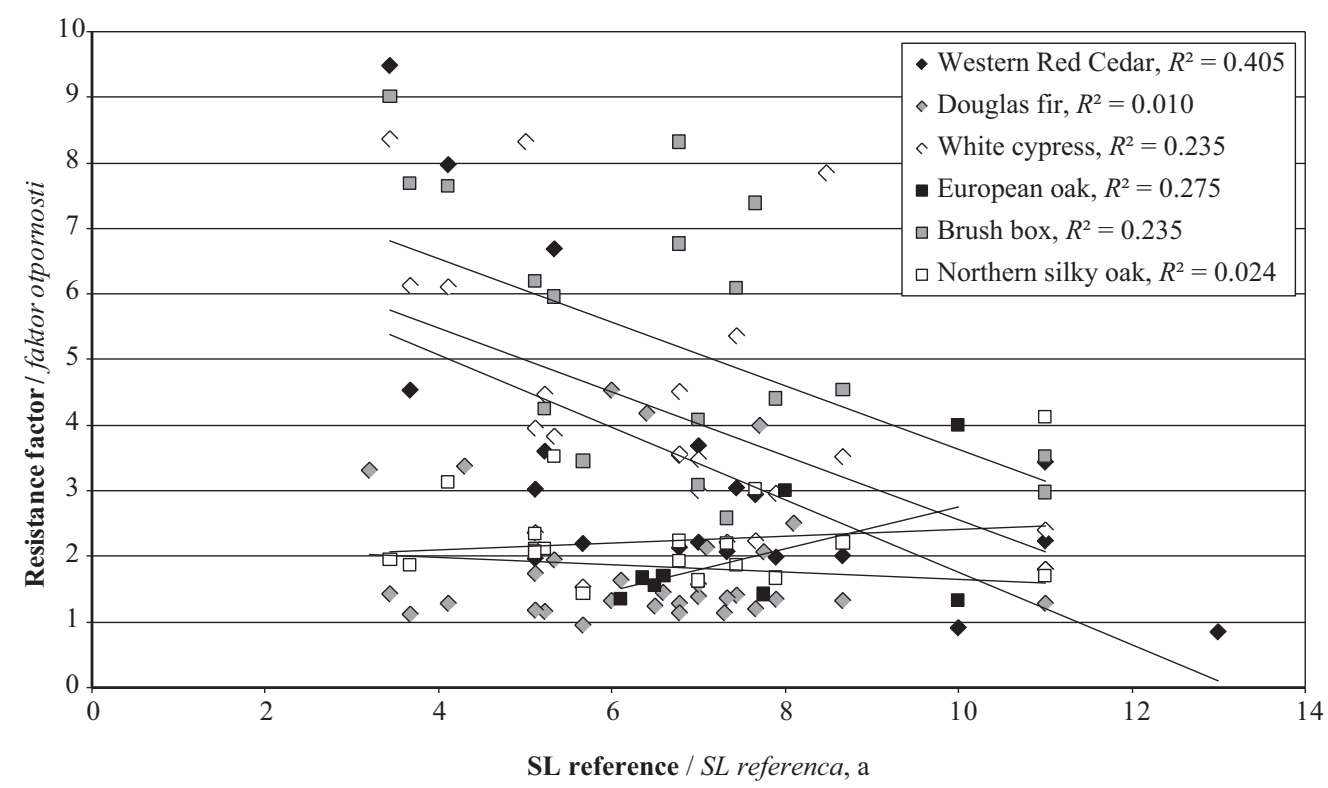

Figure 5 Resistance factors of six selected wood species related to the mean or median service life in years of the reference species

Slika 5. Čimbenici otpornosti za šest vrsta drva u odnosu prema srednjoj vrijednosti ili medijanu životnoga vijeka referentne vrste drva

English oak (Quercus robur), Scots pine and Norway spruce (Picea abies) and the relative effects of durability measures, therefore, need to be verified.

The influence of the test methods on the resulting resistance factors of a certain wood species is superposed by the effect of climatic conditions. Basically it is the microclimate within a wood specimen that determines the conditions for fungal growth and decay. Consequently, the combination of mesoclimate (environmental conditions at the test site) and the design of the respective test set up affect the microclimate. This is demonstrated by considering resistance factors calculated for Douglas fir, which varied as follows: in double layer tests between 1.08 and 4.54, in uncoated L-joint tests between 0.90 and 1.74, in coated L-joint tests between 1.12 and 1.95, and in cross brace tests between 2.00 and 2.13 (Tab. 8). Obviously the variation within one test method was higher compared to the variation between the different test methods, which coincides with the findings of De Groot (1992), who exposed Southern yellow pine sapwood in Mississippi, USA, and in a rainforest in Panama using 18 different test designs. While he found a significant impact of the test design in the temperate location, differences diminished in the tropical rainforest. Within this study, test data from different test methods at the same test location were available only for a few wood species, so the potential effect of the test configurations was not quantifiable.

\section{CONCLUSIONS}

\section{ZAKLJUČCI}

We do not claim that this literature and data survey on above ground durability tests is complete. This is mainly due to the fact that many studies around the world are known to exist, but respective data are not freely available. The lack of freely available data is strongly indicated through the fact that $80 \%$ of durability records used for this study was unpublished. Furthermore, in many cases information was too condensed and incomplete, which is inescapable for journal articles, but prevented the data transformation necessary to calculate specimen service life measures.

The range of test results observed for each wood species further highlighted that the current timber durability classification systems, which assign a species to a durability class irrespective of site and design, are not precise enough for many scientific and engineering purposes. Data need to meet a number of requirements in terms of specificity, background information and formatting.

We conclude that further research into the relative effects of climate on decay progress amongst different species is required, and future comparative studies should focus not only on differences between test sites, but also on different test configurations at the same location to determine the effects of structural design on timber durability. To facilitate this goal, a suitable platform is needed to increase the quantity and availability of useful data. Service life related durability recordings should be shared amongst the scientific community to allow the exchange and advancement of knowledge in this field. The value of these durability data is expected to rise through collaborative comparative studies and meta analyses.

Similar or even more complex challenges are faced for predicting the service life of modified and preservative treated wooden material because additional information of treatment agents and processes are needed. Wood used outdoors is commonly treated with different wood preserving agents and formulations, and field studies on the durability of preservative treated and modified timber include additional parameters, including preservative type, penetration and retention. 
For these reasons, a proposal for a 'Durability Data Base' has been made to the 'International Research Group on Wood Protection, IRG-WP' (Brischke et al. 2012). Requirements and feasible formats for durability recordings have been suggested for all types of wood products: naturally durable timber, thermally and chemically modified timber, water repellent and preservative treated timber as well as for composite products. The database shall allow availability of test results from field and laboratory studies dealing with wooddegrading fungi, insects, and marine borers.

\section{Acknowledgements - Zahvale}

The authors would like to express their special thanks to all colleagues, who have contributed to this study with test data, long-term experience in the field and good advice.

\section{REFERENCES}

\section{LITERATURA}

1. Augusta, U., 2007: Untersuchung der natürlichen Dauerhaftigkeit wirtschaftlich bedeutender Holzartenbei verschiedener Beanspruchung im Außenbereich. Dissertation, University of Hamburg.

2. Brischke, C., 2007: Investigation of decay influencing factors for service life prediction of exposed wooden components. Dissertation, University of Hamburg.

3. Brischke, C.; Rapp A. O., 2008a: Influence of wood moisture content and wood temperature on fungal decay in the field: observations in different micro-climates. Wood Sci. Tech. 42: 663-677.

http://dx.doi.org/10.1007/s00226-008-0190-9

4. Brischke, C.; Rapp, A. O., 2008b: Dose-response relationships between wood moisture content, wood temperature and fungal decay determined for 23 European field test sites. Wood Sci. Tech. 42: 507-518. http://dx.doi.org/10.1007/s00226-008-0191-8

5. Brischke, C.; Welzbacher, C. R.; Rapp, A. O.; Augusta, U.; Brandt, K., 2009: Comparative studies on the inground and above-ground durability of European oak heartwood (Quercus petraea Liebl. and Quercus robur L.). Eur. J. Wood Prod. 67:329-338.

http://dx.doi.org/10.1007/s00107-009-0329-x

6. Brischke, C.; Rapp, A. O., 2010: Service life prediction of wooden components - Part 1: Determination of doseresponse functions for above ground decay. Document IRG/WP 10-20439. International Research Group on Wood Protection, Stockholm

7. Brischke, C.; Frühwald Hansson, E., 2011: Modeling biodegradation of timber - Dose-response models for above-ground decay and its climate-dependent variability. International Conference on Structural Health Assessment of Timber Structures, SHATIS '11, June 16-17, 2011, Lisbon, Portugal.

8. Brischke, C.; Welzbacher, C. R.; Meyer, L.; Bornemann, T.; Larsson-Brelid, P.; Pilgård, A.; Frühwald Hansson, E.; Westin, M.; Rapp, A. O.; Thelandersson, S.; Jermer, J., 2011: Service life prediction of wooden components - Part 3: Approaching a comprehensive test methodology. Document IRG/WP/11-20464. International Research Group on Wood Protection, Stockholm.

9. Brischke, C.; Meyer, L.; Alfredsen, G.; Humar, M.; Francis, L. P., 2012: Durability of timber products - Part 2: Proposal for an IRGWP - durability data base. Document
IRG/WP/12-20497. International Research Group on Wood Protection, Stockholm.

10. Carey, J. K.; Purslow, D. F.; Savory, J. G., 1981: Proposed method for out-of-ground contact trials of exterior joinery protection systems. Document IRG/WP 2157. International Research Group on Wood Protection, Stockholm.

11. CEN European Committee for Standardization 1989: EN 252. Wood preservatives. Field test methods for determining the relative protective effectiveness in ground contact.

12. CEN European Committee for Standardization, 1993: EN 330 Wood preservatives - Field test method for determining the relative protective effectiveness of a wood preservative for use under a coating and exposed out of ground contact - L-joint method.

13. CEN European Committee for Standardization, 1994: EN 350-1 Durability of wood and wood-based products - Natural durability of solid wood - Part 1: Guide to the principles of testing and classification of the natural durability of wood.

14. CEN European Committee for Standardization, 2003: CEN TS 12037 Wood preservatives. Field test method for determining the relative protective effectiveness of a wood preservative exposed out of ground contact. Horizontal lap-joint method.

15. CEN European Committee for Standardization, 2006: EN 335 Durability of wood and wood-based products Definition of use classes.

16. Da Costa, E. W. B., 1979: Comparative decay resistance of Australian timbers in accelerated laboratory tests." Aus. For. Res. 9:119-135.

17. De Groot, R. C., 1992: Test assemblies for monitoring decay in wood exposed above ground. Inter. Bio. Bio. 29: 151-175. http://dx.doi.org/10.1016/0964-8305(92)90014-F

18. Dickinson, D, 2005: The factor method in wood preservation - A proposal for future progress from the COST E37 Task Force. COST E37 5th meeting of Task force "Performance Classification”, Oslo, Norway, $18^{\text {th }}$ June 2005.

19. Edlund, M.-L., 2004: Durability of some alternatives to preservative treated wood. Document IRG/WP 04-30353. International Research Group on Wood Protection, Stockholm.

20. Edlund, M.-L.; Jermer, J., 2007: Durability of some alternatives to preservative-treated wood. Progress report 2: Results from field tests after 5 years'exposure. Document IRG/WP 07-30442. International Research Group on Wood Protection, Stockholm.

21. Eslyn, W. E.; Highley, T. L.; Lombard F. F., 1985: Longevity of untreated wood in use above ground. For. Prod. J. 35: 28-35.

22. Evans, F.; Alfredsen, G.; Flæte, P. O., 2011: Natural durability of wood in Norway - Results after eight years above ground exposure. The Nordic-Baltic Network in Wood Material Science and Engineering (WSE): Proceedings of the $7^{\text {th }}$ meeting, 2011, 1-6.

23. Flæte, P. O.; Alfredsen, G.; Evans, F. G., 2008: Comparison of four methods for natural durability classification after 2.5 years exposure. ProLigno 4: 15-24.

24. Flæte, P. O.; Alfredsen, G.; Evans, F. G., 2011: Natural durability of wood tested in different environments in Northern Europe. Document IRG/WP 11-10747. International Research Group on Wood Protection, Stockholm.

25. Foliente, G. C., 2000: Developments in Performance-Based Building Codes and Standards. For. Prod. J. 50: 12-20.

26. Francis, L. P.; Norton, J., 2005: Above-ground durability estimation in Australia. Results after 16 years exposure. 
.... Brischke, Meyer, Alfredsen, Humar, Francis, Floete, Larsson-Brelid: Natural Durability...

Document IRG/WP 05-20314. International Research Group on Wood Protection, Stockholm.

27. Francis, L. P.; Norton, J., 2006: Predicting the decay resistance of timber above-ground: 1. Climate effects. Document IRG/WP 06-20330. International Research Group on Wood Protection, Stockholm.

28. Francis, L. P.; Swain, A. J., Morrell, J. J., 2007: Predicting the decay resistance of timber above-ground: 2 . When can reliable field data be obtained? Document IRG/WP 07-20368. International Research Group on Wood Protection, Stockholm.

29. Fredriksson, M., 2010: A critical literature review of moisture and temperature conditions in wood exposed outdoors above ground. Report TVBM-3152. Lund Institute of Technology, Lund University, Division of Building Materials.

30. Gobakken, L. R.; Viitanen, H., 2004: Inventory for existing test methods for fungi. Working Document of TF Performance Classification of COST Action E 37.

31. Highley, T. L., 1995: Comparative durability of untreated wood in use above ground. Inter. Bio. Bio. 35: 409-419. http://dx.doi.org/10.1016/0964-8305(95)00063-1

32. ISO International Standardisation Organisation, 2000: ISO 15686-1. Building and constructed assets - Service life planning - Part 1: General principles.

33. MacKenzie, C. E.; Wang, C-H.; Leicester, R. H.; Foliente, G. C.; Nguyen, M. N., 2007: Timber service life design guide. Project number PN07.1052. Forest and Wood Products Australia Limited. www.fwpa.com.au

34. Norton, J.; Francis, L. P., 2008: Effect of surface-applied treatments on the above-ground performance of simulated timber joinery. Aus. For. J. 71: 100-106. http://dx.doi.org/10.1080/00049158.2008.10676276

35. Palanti, S.; Feci, E.; Torniai, A. M., 2011: Comparison based on field tests of three low-environmental-impact wood treatments. Inter. Bio. Bio. 65: 547-552. http://dx.doi.org/10.1016/j.ibiod.2010.12.012

36. Råberg, U.; Edlund, M.-L.; Terziev, N.; Land, C. J., 2005: Testing and evaluation of natural durability of wood in above ground conditions in Europe - an overview. J. Wood Sci 51: 429-440. http://dx.doi.org/10.1007/s10086-005-0717-8

37. Rapp, A. O.; Augusta, U.; Brandt, K.; Melcher, E., 2010: Natürliche Dauerhaftigkeit verschiedener Holzarten Ergebnisse aus acht Jahren Feldversuch. In: Holzforschung Austria (Ed.) Wiener Holzschutztage 2010, 2526.11.2010 Wien.

38. Standards Australia, 2008: AS 5604 Timber - Natural durability ratings, Australian Standard distributed by SAI Global Limited. www.saiglobal.com.
39. Stirling, R., 2009: Natural durability classification systems used around the world. Document IRG/WP 0910694. International Research Group on Wood Protection, Stockholm.

40. Thelandersson, S.; Isaksson, T.; Suttie, E.; Frühwald Hansson, E.; Toratti, T.; Grüll, G.; Viitanen, H.; Jermer, J., 2011: Quantitative design guideline for wood in outdoor above ground applications. Document IRG/WP 1120465. International Research Group on Wood Protection, Stockholm.

41. Van Acker, J.; Militz, H.; Stevens, M., 1999: The significance of accelerated laboratory testing methods determining the natural durability of wood. Holzforschung 53: 449-458.

42. Van Acker, J.; Stevens, M., 2003: Biological durability of wood in relation to end-use - Part 2: The use of an accelerated outdoor L-joint performance test. Holz RohWerkst. 61: 125-132.

43. Viitanen, H.; Vinha, J.; Salminen, K.; Ojanen, T., Peuhkuri, R.; Paajanen, L.; Lähdesmäki, K., 2010: Moisture and bio-deterioration risk of building materials and structures. J. Build. Phys. 33: 201-224. http://dx.doi.org/10.1177/1744259109343511

44. Wang, C.-H.; Leicester, R. H.; Nguyen, M. N., 2008a: Decay above ground. Manual No. 4. CSIRO Sustainable Ecosystems, Urban Systems Program, Highett, Victoria.

45. Wang, C.-H.; Leicester, R. H.; Nguyen, M. N., 2008 b. Equations for use in a service life design guide. Manual No. 11. CSIRO Sustainable Ecosystems, Urban Systems Program, Highett, Victoria.

46. Willeitner, H.; Peek, R.-D., 1997: The natural durability story. Document IRG/WP 97-2011. International Research Group on Wood Protection, Stockholm.

\section{Corresponding address:}

Professor CHRISTIAN BRISCHKE, Ph.D.

Leibniz University Hannover

Faculty of Architecture and Landscape Science

Herrenhäuser Str. 8

D-30419 Hannover, GERMANY

e-mail: brischke@ibw.uni-hannover.de 